\title{
Central Control of Feeding Behavior by the Secretin, PACAP, and Glucagon Family of Peptides
}

\author{
Revathi Sekar, Lei Wang and Billy Kwok Chong Chow* \\ School of Biological Sciences, The University of Hong Kong, Hong Kong, China
}

Constituting a group of structurally related brain-gut peptides, secretin (SCT), pituitary adenylate cyclase-activating peptide (PACAP), and glucagon (GCG) family of peptide hormones exert their functions via interactions with the class B1 G protein-coupled receptors. In recent years, the roles of these peptides in neuroendocrine control of feeding behavior have been a specific area of research focus for development of potential therapeutic drug targets to combat obesity and metabolic disorders. As a result, some members in the family and their analogs have already been utilized as therapeutic agents in clinical application. This review aims to provide an overview of the current understanding on the important role of SCT, PACAP, and GCG family of peptides in central control

OPEN ACCESS

Edited by:

Hubert Vaudry,

University of Rouen, France

Reviewed by:

Lourdes Mounien,

Aix-Marseille University, France

SuJean Choi,

Marquette University, USA

*Correspondence:

Billy Kwok Chong Chow

bkcc@hku.hk

Specialty section:

This article was submitted to

Neuroendocrine Science,

a section of the journal

Frontiers in Endocrinology

Received: 01 November 2016

Accepted: 18 January 2017

Published: 07 February 2017

Citation:

Sekar $R$, Wang $L$ and Chow BKC (2017) Central Control

of Feeding Behavior by the

Secretin, PACAP, and Glucagon

Family of Peptides.

Front. Endocrinol. 8:18. doi: 10.3389/fendo.2017.00018

\section{of feeding behavior.}

\footnotetext{
Keywords: secretin, PACAP, and glucagon family peptides, hypothalamus, feeding behavior, energy homeostasis, metabolic diseases
}

\section{INTRODUCTION}

Secretin (SCT), pituitary adenylate cyclase-activating peptide (PACAP), and glucagon (GCG) family or SCT family, a group of short peptides that were classified based on their structural homology and named after the first hormone discovered, include SCT, PACAP, vasoactive intestinal peptide (VIP), GCG, glucagon-like peptide-1 (GLP-1), GCG-like peptide-2 (GLP-2), glucose-dependent insulinotropic polypeptide (GIP), growth hormone-releasing hormone (GHRH), and peptide histidine isoleucine (PHI) or peptide histidine methionine (1). While sharing some biological functions, each of these hormones possesses distinct physiologic actions such as the involvement of SCT in water homeostasis (2). Similar to their ligands, receptors mediating functions of the peptides are structurally related and are grouped in the class B G protein-coupled receptors $(3,4)$. Recent pharmacological interests for these receptors have paved way for novel therapeutic strategies for intervention of pathological conditions (5-8). For instance, liraglutide and exenatide (GLP-1 receptor agonists) are being used for treating diabetes (5).

Feeding is a complex behavior involving the integration of homeostatic systems that sense energy balance with hedonic (reward) behavior (9). Areas in the central nervous system (CNS) that appear to be important for regulation of feeding behavior are distributed across regions of forebrain and caudal brain stem $(10,11)$. Of particular significance is the hypothalamic neural circuitry, long known to be involved in the control of energy homeostasis in response to various endocrine, nutritional, metabolic, and thermal signals. The role of hypothalamus in energy homeostasis regulation has been discussed in detail in several review articles $(10,12-16)$. Arcuate nucleus (ARC), paraventricular nucleus (PVN), ventromedial hypothalamus (VMH), dorsomedial hypothalamus $(\mathrm{DMH})$, and lateral hypothalamus $(\mathrm{LH})$ are hypothalamic regions with reciprocal 
connections that are known to be involved in regulation of food intake and energy homeostasis. In the ARC above the median eminence, neurons expressing neuropeptide Y (NPY) and agouti gene-related protein (AgRP) stimulate food intake and are found medially, while pro-opiomelanocortin (POMC) (precursor of $\alpha$-melanocyte-stimulating hormone; $\alpha$-MSH) and cocaine- and amphetamine-regulated transcript (CART) induce anorexia and are coexpressed in the neuronal population of lateral ARC. These neurons project to the PVN which controls feeding and provides preganglionic autonomic output to the brainstem. NPY reduces energy expenditure and stimulates food intake through the Y1 and Y5 receptors in the PVN. Conversely, CART inhibits NPY-induced feeding (17-19). Also, POMC and its products such as $\alpha-\mathrm{MSH}$ suppress feeding behavior. AgRP is an endogenous antagonist of $\alpha-\mathrm{MSH}$ and, therefore, increases food intake and weight. Other hypothalamic peptides, such as melanin-concentrating hormone and hypocretin, are orexigenic in nature and are expressed in distinct populations of neurons in the lateral hypothalamic area (20-22). Another important site in regulation of feeding behavior is caudal brain stem. In the brain stem, neurons in the nucleus tractus solitarius (NTS) and dorsal motor nucleus of the vagus (DMV) receive and integrate inputs from vagus nerve, which is involved in sensing nutrient accumulation in the stomach and the duodenum (23). Highly interconnected with the hypothalamus, brainstem regulates responses to fasting through ascending projections to the hypothalamus (10) and short-term satiety signals through descending projections from the hypothalamus (24). Apart from the brain circuits regulating hunger and satiety, nuclei embedded within the mesolimbic reward circuitry [ventral tegmental area (VTA) and nucleus accumbens (NAc)], which are well known for their importance in reinforcing properties of drugs of abuse and natural rewards (25), as well as nuclei in the amygdale and hippocampus are involved in the rewarding effects of food (26).

The SCT family peptides and their receptors have been found to exist in various brain regions, including hypothalamus, implying their neuroactive functions $(27,28)$. Most of them have also been found to be important in the central regulation of energy balance (29). Therefore, in the sections below, we have reviewed in detail the role of SCT family hormones in the central control of feeding behavior.

\section{SECRETIN}

Secreted from the S-cells of the duodenum in response to acid, SCT is a 27-amino acid peptide and the first ever hormone discovered (30). SCT primarily functions in the gastrointestinal tract to stimulate bicarbonate secretion from the pancreas to neutralize acid (31). A century-long research has gone into studying the gastrointestinal functions of SCT, and only recently it has been found as a neuropeptide (2,32-36). As we summarized before (28), SCT was found to be expressed in multiple brain sites, including PVN, supraoptic nucleus (SON), and ARC of hypothalamus, NTS of brainstem, central amygdala (CeA), hippocampus, and cerebral cortex $(37,38)$. SCT receptor (SCTR) expressions were also found in PVN, SON, and ARC of the hypothalamus, among other brain regions (39). In spite of contradictory evidences in the past (40-42), our laboratory has recently confirmed an anorectic effect of peripheral and central SCT in mice (39), supported by our findings that intracerebroventricular (i.c.v.) and intraperitoneal (i.p.) injections of SCT reduced food intake in wild-type mice. This observation was absent in SCTR knockout $\left(\mathrm{SCTR}^{-/-}\right)$mice, further confirming the specificity of SCT-SCTR axis in regulating feeding behavior.

The previous review from our lab (28) has concluded that circulating SCT might not cross the blood-brain barrier (BBB) for specifically exerting its anorectic effect $(38,39)$, although SCT has been shown to be able to cross the BBB (43). Thus peripheral SCT, through SCTR in the intestinal vagal afferents, communicated to the brain to bring about satiety control without causing conditioned taste aversion (CTA) $(39,44)$. However, a very recent study has provided another piece of the puzzle on the appetite regulation by peripheral SCT. By using male oxytocin (OXT)monomeric red fluorescent protein 1 (mRFP1) transgenic rats, the study showed that i.p. SCT $(100 \mu \mathrm{g} / \mathrm{kg})$, apart from inducing a reduction in food intake, stimulated mRFP1 fluorescence (OXT indicator) in the dorsal division of the parvocellular PVN $(\mathrm{dpPVN})$ and increased mRFP1-positive granules in the axon terminals of dpPVN OXT neurons in the NTS. An upregulation of c-Fos expression was also observed in the NTS and OXT neurons of dpPVN. Therefore, peripheral SCT might regulate feeding behavior, at least in part, via an OXTergic pathway from the dpPVN to the NTS (45).

Consistently, central SCT is also able to reduce food intake. It has been shown that central SCT induced c-Fos immunoreactivities in the ARC and PVN of hypothalamus. In the ARC, POMC neurons were found to be colocalized with activated c-Fos as well as with SCTR. An increase in POMC and a reduction in AgRP transcript levels were observed in the ARC after i.c.v. and i.p. SCT $(39,46)$. In addition, it has been reported that central and peripheral SCT increased melanocortin-4 receptor (MC4R) mRNA in the PVN, and administration of MC4R antagonist, SHU9119, in the PVN reduced the anorectic effect of central and peripheral SCT, indicating the involvement of melanocortin system $(39,46)$. We previously showed that $\mathrm{K}^{+}$-induced depolarization of hypothalamic explants released SCT endogenously through voltage-gated sodium and calcium channels, suggesting that this endogenous SCT could function as a neurotransmitter in the region $(34,35)$. Taken all together, SCT has been suggested as a pleiotropic regulator of feeding behavior and neuroendocrine signaling in the hypothalamus. Microinjection of SCT into the $\mathrm{CeA}$ has been recently shown to reduce cumulative food intake through cAMP-activated protein kinase pathway, while electrophysiological recordings indicated that SCT may exert its anorectic actions, at least in part, by modulation of spontaneous firing of CeA neurons (47).

Absence of a truly functional SCTR antagonist is partly a hindrance for studying the region-specific (hypothalamus or amygdala) role of SCT in modulating food intake behavior. Recent establishment of several animal models such as $\mathrm{SCT}^{-1-}$ or $\mathrm{SCTR}^{-/}$as well as the SCT $\mathrm{SC}^{\mathrm{H} / \mathrm{ll}}$ for cell-specific knockout of SCT should help to reveal the relationship between SCT and 
anorectic functions. Research on food intake modulations by SCT has been initiated for the past few years but still requires further efforts to test its potential in therapeutic interventions.

\section{PITUITARY ADENYLATE CYCLASE- ACTIVATING PEPTIDE}

Pituitary adenylate cyclase-activating peptide, a 38-residue peptide hormone, was first isolated from ovine hypothalamic tissue as a hypophysiotropic peptide that would activate adenylate cyclase in cultured rat pituitary cells (48) and is widely distributed in the body including brain, gonads, and adrenal gland (49, 50). Various regions of the brain like central thalamic nuclei, amygdaloid complex, and hippocampus expressed PACAP and yet the most abundant expression was found in the ARC, PVN, $\mathrm{VMH}$, and SON of the hypothalamus $(50,51)$, which has been well documented to be involved in appetite regulation. Double labeling studies have shown PACAP to be colocalized with POMC neurons of the ARC but not POMC neurons within the brain stem (52). Receptors for PACAP (PAC1R and/or VPAC2R) were also found to be expressed in approximately half of POMC neurons $(53,54)$ and a significant proportion of NPY neurons $(53,54)$. Consistent with its distribution pattern in the brain, i.c.v. administration of PACAP was found to reduce food intake by several studies (55-57). Notably, in rat, Mizuno's group showed that PACAP induced a long-lasting reduction of food consumption (58). As we have reviewed before (28), a study showed that $100 \mathrm{nM}$ PACAP increased POMC mRNA, $\alpha-\mathrm{MSH}$ tissue content as well as $\alpha$-MSH release in mediobasal hypothalamic explants $(53,54)$. Another study further revealed that central PACAP stimulated c-Fos expression in POMC neurons and increased POMC and MC4R transcripts in the ARC; PACAPspecific receptor (PAC1R) knockout mice had lower POMC transcript levels in the ARC compared to wild-type animals and pre-injection of SHU9119, MC3R/MC4R antagonist, abolished the hypophagic effects of i.c.v.-PACAP, suggesting that PACAP might act through $\mathrm{PAC1R}$ receptor and then melanocortin system to exert its anorectic effect (57). Using AtT20PL, a clone of the AtT20 mouse corticotroph tumor cells stably transfected with rat POMC 5' promoter-luciferase fusion gene, PACAP and VIP were found to increase the POMC promoter activity and expression via a PKA-independent intracellular signaling pathway (59).

Intra-PVN injection of PACAP has been shown to reduce food intake as well as lead to significant reductions in meal size, duration, and total time spent eating (60), consistent with the loss-of-function study showing that there was a pronounced hyperphagia in PVN-lesioned animals (61), and PACAP receptor-specific study showing that the feeding behavior was primarily controlled by PAC1R and this receptor subtype was abundantly distributed in the PVN (60). Although PVN has been suggested as the predominant site of action for PACAP-mediated hypophagia, the PACAP stimulation of the VMH may serve primarily to stimulate energy expenditure (60). Direct acute injection of PACAP into the $\mathrm{VMH}$, a region heavily expressing PAC1R, was able to inhibit food intake for $6 \mathrm{~h}$ which could be reversed by the PAC1R antagonist. Intra-VMH injection of
PACAP also increased POMC mRNA in the ARC while not affecting NPY and AgRP mRNA levels (62). Previous studies have shown that PACAP is capable of modulating the activation of ionotropic glutamate receptors $(63,64)$. Recently, it has been shown that glutamatergic signaling via NMDA receptors was required for the hypophagic effects of intra-VMH PACAP (65). A novel model of binge behavior that could temporally separate homeostatic feeding from palatable food-driven (hedonic) feeding behavior (66), has shown that the microinjection of PACAP into NAc mimics the actions of GABA agonists and reduces the intake of palatable food without altering homeostatic feeding, while microinjection of PACAP into the VMH mimics the actions of AMPA by decreasing homeostatic feeding without altering hedonic feeding. Furthermore, it has been shown that transcript levels of PACAP in the VMH was regulated according to energy status, as fasting reduced and high-fat diet increased PACAP expression in VMH (67).

Recently, monosynaptic interactions of PACAP-expressing neurons in the VMH with appetite-suppressing POMC neurons of the ARC have been shown (68). Nevertheless, this study also showed, using channel rhodopsin-assisted circuit mapping, that appetite-stimulating AgRP neurons in the ARC had excitatory PACAPergic afferents originating within the PVN. Incidentally, a previous study has reported that PACAP could stimulate NPY neurons to elevate cytosolic $\mathrm{Ca}^{2+}$ levels (69). These exciting new findings suggested that, based on their neuroanatomical location, PACAP could stimulate both orexigenic and anorexigenic effects (70). A very recent study showed a role of PACAP/PAC1 signaling during light-regulated feeding behavior (71), adding more complexity on the appetite regulation by PACAP in the hypothalamus. Therefore, further detailed studies are required to understand how these pathways interact under various energy states and converge to modulate feeding behavior.

Apart from its anorectic role, local PVN as well as i.c.v. infusion of PACAP-38 significantly induced plasma glucose concentration, endogenous glucose production, and c-Fos immunoreactivity in the autonomic neurons in the PVN. These neurons project to preganglionic sympathetic neurons in the spinal cord and are involved in hepatic glucose production (72). Furthermore, PACAP has been shown to interact with other peptides to modulate feeding behavior. Central administration of PACAP provokes increases in hypophysiotropic neurohormones in the hypothalamus, such as vasopressin, GnRH, somatostatin, and CRF $(73,74)$. In chicks $(75)$ and goldfish $(76)$, it has been shown that anorectic effect of central PACAP was inhibited by $\mathrm{CRH}$ receptor antagonist, astressin, and $\alpha$-helical $\mathrm{CRH}_{(9-41)}$, respectively, and $\mathrm{GnRH} 2$ has been found to mediate $\mathrm{CRH}$-signaling pathway in goldfish (77). PACAP mRNA was found to be colocalized with steroidogenic factor-1in the VMN and leptin signaling was required for normal PACAP expression in these cells, while blocking of endogenous central PACAP signaling attenuated leptin-stimulated hypophagia and hypothermia (67). Consistently, i.p. administration of PACAP has been found to suppress appetite with a decrease in plasma ghrelin and an increase in plasma GLP-1 and leptin $(78,79)$. For its integrative role in glucose and energy homeostasis, PACAP receptor subtype-specific agonists and/or antagonists are being 
considered as potential therapeutic agents for metabolic disorders in addition to appetite disorders.

\section{VASOACTIVE INTESTINAL PEPTIDE}

Distributed throughout the gastrointestinal tract $(80,81)$ and CNS including cerebral cortex, suprachiasmatic nucleus (SCN), and PVN of the hypothalamus and thalamus $(82,83)$, VIP is a 28-amino acid peptide hormone known for its role in vasodilation and hypotension acting through VPAC1R and VPAC2R receptors. VPAC1R expression has been found mainly in the cerebral cortex and hippocampus, while VPAC2R was expressed in the thalamus, midbrain and in the PVN and SON magnocellular cells and SCN of the hypothalamus $(83,84)$. Previous studies have demonstrated that plasma VIP concentrations increased following either a carbohydrate meal or water loading (85), and short-term fasting altered the VIP levels in the hypothalamus and other brain regions, suggesting a potential for VIP in modulating appetite and food intake (86). Indeed, i.c.v. administration of VIP induced anorexia in chicken $(87,88)$, goldfish $(89,90)$, and rat (91). Disruption in food intake and metabolic rhythm occurred in VIP and VPAC2R knockout mice (92). VIP could possibly stimulate hypothalamic-pituitary-adrenal (HPA) axis as intra-PVN injection of VIP increased secretion of ACTH and corticosterone (93), possibly by activating the CRH neurons (94). Additionally, stimulation of hypothalamic explants by VIP significantly stimulated the release of $\alpha-\mathrm{MSH}$ (91), suggesting VIP could also work through the activation of melanocortin system to inhibit food intake. As mentioned earlier, cell line studies with transfected rat POMC promoter-luciferase fusion gene have shown that VIP induces POMC promoter activity through a PKA-independent pathway (59). Recently, VIP knockout mice were shown to have a disrupted pattern of circadian feeding behavior resulting in a significantly reduced nocturnal/diurnal feeding along with reduced body weight and fat mass accumulation $(78,79)$. The study also showed that, in VIP knockout mice, the release of anorexigenic hormones, such as GLP-1, leptin, PYY, and insulin was altered in both fasting and post-prandial conditions, revealing a possibility of VIP cross-talking with other hormones to inhibit food intake. However simultaneously, orexigenic hormones were also found to be altered suggesting the role of VIP in both anorexigenic and orexigenic effects (78, 79). There were also reports indicating an absence of anorectic effects by VIP as i.c.v. injection of VIP did not influence appetite in fasted mice (57) and administration of VIP receptor antagonist in the PVN had no effect on food intake in rats (94). With such contrasting evidences, the role of VIP on appetite control remains currently unclear.

\section{GLUCAGON}

Derived from proglucagon that contains sequences for GLP-1 and GLP-2, GCG is a 29-amino acid peptide hormone secreted by pancreatic $\alpha$ cells in response to low blood glucose. Counteracting hypoglycemia, it antagonizes insulin action by stimulating hepatic glucose synthesis and mobilization. In contrast to its peripheral action, recent reports have shown that hypothalamic action of GCG inhibited hepatic glucose production $(95,96)$. Its role in energy homeostasis and metabolism has been reviewed in detail before (97-99). Also as we have reviewed before (28), peripheral GCG induced satiety in humans $(100,101)$ and in rats $(102,103)$ without causing CTA (104); GCG affected meal size rather than meal interval (105); and hepatic vagal afferents were found to mediate this effect of peripheral GCG (106). In addition, another study reported that subcutaneous injection of GCG was able to reduce appetite and through immunohistochemical analysis c-Fos expression could be detected in the NTS, area postrema (AP), and CeA but absent in the ARC, PVN, and DMH regions of the hypothalamus, suggesting the involvement of brainstem and amygdala in the appetite control by peripheral GCG (107). GCG receptor (GCGR) distribution has been found in the dorsal vagal complex (DVC) of brainstem (108). A recent study investigating the role of GCG in high-protein feeding has demonstrated that elevated circulating GCG found during high-protein feeding acted in the DVC through GCGR-dependent PKA-Erk1/2-K $\mathrm{K}_{\text {ATP }}$ signaling cascade to contribute to the effect of high-protein feeding (109). However, relatively low levels of GCGR were also found in the hypothalamus, and it is noteworthy that circulatory GCG has been shown to suppress glucose sensing via $\mathrm{LH}, \mathrm{DMH}$ and $\mathrm{VMH}$ neurons of hypothalamus, hence the possibility of hypothalamic activation in appetite control by peripheral GCG could not be excluded (110). While the mechanisms behind the anorectic effect of peripheral GCG were not fully understood, there were also reports suggesting that peripheral GCG increased food intake (111).

Central administration of GCG has been observed to induce anorexia in rats $(112,113)$, chicks $(114,115)$, and sheep (116) with much higher anorectic effect appeared after i.c.v. GCG than its peripheral effect in rats (112). Although the mechanisms underlying satiety regulation by central GCG remains a mystery, a previous review has discussed several possibilities. For example, it suggested the stimulation of hypothalamic corticotropinreleasing factor and activation of HPA axis to be involved in the anorectic effect of GCG (117). Microinjection of GCG into the LH reduced appetite and stimulated sympathetic activity (118). Although high levels of immunoreactive GCG and relatively low levels of GCGR were found in the hypothalamus (108), the role of hypothalamic neurons in appetite control by GCG was not clear, until a recent report proved that central GCG reduced appetite through hypothalamic pathway (119). Hypothalamic GCG activated GCGR to stimulate downstream PKA pathway in the hypothalamic ARC, as i.c.v. co-infusion of the GCGR antagonist des-His ${ }^{1}-\left[\mathrm{Glu}^{9}\right]$ GCG amide or the PKA inhibitor H-89 negated the ability of central GCG to induce anorexia. And as the downstream factor of PKA, central GCG injection also reduced protein levels of $\mathrm{Ca}^{2+}$-calmodulin-dependent protein kinase kinase $\beta(\mathrm{CaMKK} \beta)$ and its downstream target phosphorylated AMP-activated protein kinase (AMPK) in the ARC. AMPK was upstream Acetyl-CoA carboxylase (ACC), and it was hence observed that the injection of a constitutively active AMPK virus in the ARC was able to recover the decrease of ACC caused by central GCG and attenuated the anorectic effects of GCG. Consistent with above findings as well as the co-localization of the GCGR 
in AgRP neurons of the ARC (95), a significant reduction in the expression of AgRP was observed after central GCG injection. Diet-induced obesity abolished the anorectic effects of GCG but it was restored by molecular inhibition of CaMKK $\beta$ in the ARC via adenoviruses encoding dominant negative CaMKK $\beta$. Central GCG, therefore, exerted its acute anorectic effects through PKA/ AMPK/CaMKK $\beta$-dependent pathways in the ARC and CaMKK $\beta$ mediated its obesity-induced hypothalamic resistance (119). Taken together, even though several aspects of the central GCG's role in controlling feeding behavior have been discussed above and also by other studies, further research is still required to get better understanding and shed light on the beneficial effects by coordination of central GCG with other hormones such as insulin and GLP-1.

\section{GLUCAGON-LIKE PEPTIDE-1}

Processed from the preproglucagon (PPG), GLP-1 is a 30 -amino acid peptide hormone secreted from the L-cells of the intestinal epithelium in response to nutrient intake (120) and acts as an incretin along with GIP stimulating glucose-dependent insulinotropic action primarily $(121,122)$. As the most explored hormone for its role in feeding behavior among the SCT family of peptides, a plethora of research has brought clarity and understanding on the peripheral and central effects of endogenous and exogenous GLP-1 on food intake and glycemic control as reviewed in several reports (123-126). Acting with GLP-1 receptors (GLP-1Rs), GLP-1 altered food intake behavior through various neural substrates, including hypothalamus (ARC, PVN, and $\mathrm{LH})$, hindbrain nuclei [parabrachial nucleus (PBN), area postrema (AP), medial NTS (mNTS)], ventral hippocampus (vHP), and nuclei embedded within the mesolimbic reward circuitry (VTA and NAc). Within these areas, the diverse neural circuitry involved in feeding control by GLP-1 has been recently reviewed in detail (127). Following nutrient intake and entry into the gastrointestinal tract, peripheral GLP-1, endogenously released from the L-cells, acted in a paracrine manner on the GLP-1R that was expressed on dendritic terminals of the celiac and gastric branches of the vagal afferents which innervated the intestine to exert its satiation effect. This vagal activation via vagal-to-NTS glutamatergic signaling relayed signals to nodose ganglion for activating the NTS neurons in the brain (128). On GLP-1 stimulation, GLP-1R on the intestinal vagal afferents also stimulated pancreatic insulin secretion via vago-vagal reflex $(128,129)$. Indeed, it was possible that peripheral GLP-1 through a vagal afferent-independent pathway crossed the BBB to directly activate the central GLP-1R of NTS. But a recent finding that after subdiaphragmatic vagal deafferentation, i.p. injection of GLP-1 did not affect the size of the first meal suggested otherwise (130). Although there was a question about whether peripheral GLP-1 was able to act directly in the brain, in the case of peripheral injections of long-acting GLP-1 analogs like liraglutide and exendin-4 (Ex-4), it was quite clear that they brought about reductions in food intake, at least partly by crossing the $\mathrm{BBB}$ and directly acting on the brain regions (131-133).

Central GLP-1 was a potent modulator of blood glucose utilization along with an anorectic effect (134). GLP-1 was found to be produced endogenously in the caudal nucleus of NTS and in the ventrolateral medulla while GLP-1R expression was found in the PVN, ARC, and DMH of hypothalamus as well as in the NTS, AP, and PBN of brainstem (135) revealing the functional sites of GLP-1. In the hypothalamus, i.c.v.-GLP-1 induced c-Fos expression in the PVN (134), while intra-PVN GLP-1 produced satiety $(136,137)$. PVN GLP-1R activation caused anorexia (138) and selective blockade of PVN GLP-1R resulted in hyperphagia and weight gain (139). GLP-1 (and/or GLP-1 analogs) primarily activated $\mathrm{CRH}$ and nesfatin-1 neurons (and to a lesser extent OXT neurons) in the PVN (139). Additionally, HPA axis and catecholamine release was stimulated by central GLP-1 and GLP-1R in the PVN (140). Although it has been reported that central GLP-1 induced an acute dose-dependent anorectic effect and this effect was abolished after the damage of ARC (141), there were inconsistent findings supporting and negating the anorectic actions of GLP-1 injected into the ARC (142). Thus, it warrants further research to clarify the discrepancy. Intra-LHGLP-1 induced hypophagia that was short latency and short lasting, while liraglutide reduced food intake for $24 \mathrm{~h}$ after its injection into LH (143). Local injections of GLP-1 into the VMH or the DMH also resulted in short latency, short-lasting (1-2 h) hypophagia while there was no effect for liraglutide in these areas (144). In spite of multiple action sites of GLP-1 in the hypothalamus, which indicated its indispensable role in regulating appetite via neuroendocrine pathways, some negative side effects of centrally administrated GLP-1 could not be easily ignored. For example, i.c.v. GLP-1 induced CTA effect (145) and central GLP-1R participated in LiCl-induced CTA effect as GLP-1R antagonist abolished the response. Bilateral lesions of CeA reversed the aversive behavior but not anorectic effect while bilateral lesions in the PVN was vice versa indicating that $\mathrm{PVN}$ was important for inhibition of food intake and CeA for aversive effect of GLP-1 $(137,146)$. However, it is still in need of more research to increase the knowledge of regional-specific effects of GLP-1 and expand the positive effect on clinical applications.

Caudal brain stem processing has been found to be sufficient for carrying out the various effects of peripheral and hindbrain GLP-1R activation (147). While all three nuclei of the DVC of the hindbrain (NTS, AP, DMV) expressed the GLP-1R, it was NTS GLP-1R expressing cells that were physiologically and pharmacologically more significant in modulating food intake behavior (127). It was unclear if NTS-PPG neurons expressed GLP-1R, while there was a report showing that they did not respond to GLP-1R ligands (148). Hindbrain GLP-1R activation has been found to suppress food intake via PKA-mediated suppression of AMPK activity and simultaneous activation of p44/42 MAPK in NTS neurons (149). In the same report, Ex-4, a GLP-1R agonist, activation of the same signaling cascades in GT1-7 neuronal cells and in NTS lysates supports the view that these pathways occur in GLP-1R-expressing neurons. As the mechanisms underlying the anorectic function of NTS GLP-1R activation are being studied, there were complimentary reports suggesting that intra-mNTSGLP-1 analogs mediated nausea responses and hence the anorexic effect was induced at least in part by reducing motivation to feed or by eliciting pica response and illness like 
behavior (150). GLP-1 producing neurons in the NTS projected to lateral and medial PBN in rodents $(151,152)$ and consistently, GLP-1Rs have been found to be expressed in the lateral PBN (lPBN) (153). Activation of GLP-1R by microinjection of Ex-4, in $\mathrm{PBN}$ resulted in reduced food intake and body weight along with reduced ingestion of palatable food and motivation to work for it $(152,154)$. Taken all together, these studies have provided another aspect of appetite control by GLP-1through brainstem pathways.

Glucagon-like peptide-1 neurons in the hindbrain projected directly to the NAc and VTA of the mesolimbic reward system (155), and both these areas expressed GLP-1R (153). GLP-1R activation in these nuclei led to reduction in reward-motivated behaviors for palatable food (156), alcohol (157), and cocaine (158). Injection of Ex-4 into the VTA or into the NAc core or shell reduced body weight, intake of regular chow, and intake of highfat diet while not inducing pica response or CTA $(155,156,159)$. Furthermore, injection of GLP-1R antagonist into mesolimbic nuclei increased the intake of regular chow, high-fat diet, liquid sucrose meal, and alcohol suggesting a role of endogenous GLP-1 in these nuclei $(152,157,159)$. Interestingly, blockade of GLP-1Rs in the NAc-core increased high-fat diet intake, whereas blockade of shell GLP-1Rs did not show the effect (152), indicating a difference in actions of endogenous GLP-1 in the core and shell of NAc. Furthermore, it has been recently found that GLP-1R activation in NAc core suppresses food intake by increasing glutamatergic AMPA/Kainate signaling (160). Ex vivo electrophysiological studies revealed that GLP-1R activation in NAc core activates GABAergic medium spiny neurons predominantly by a presynaptic, AMPA/kainate-mediated glutamatergic mechanism and does not involve dopamine signaling. Consistently, in vivo intra-NAc core GLP-1R activation-induced food intake suppression and body weight reduction were attenuated by blockade of AMPA/ Kainate receptors but not NMDA receptors (160).

Recently, central GLP-1 has been found to increase dopamine signaling in amygdala (161). Central activation of GLP-1R increased tyrosine hydroxylase, rate limiting enzyme for dopamine synthesis in the VTA $(161,162)$, which might contribute to increase in somatodendritic release of dopamine in the VTA (163). VTA dopaminergic neurons also projected to the amygdala where central Ex-4 acutely upregulated dopamine turnover and amygdale-dopamine receptor activation-induced satiety (161). Hence, novel VTA-amygdala dopamine circuit is being proposed as one of the underlying circuits involved in the anorectic effect of GLP-1 (161). In addition, a recent study has revealed that GLP-1R activation in vHP robustly reduced feeding, high-fat palatable food in particular while antagonizing GLP-1R in vHP region increased feeding (164), suggesting vHP as another target of GLP-1 controlling appetite. Surprisingly, the knockdown of GLP-1R did not alter the food intake in mice (165) and consistently body weight gain induced by high-fat feeding was also unaltered in GLP-1R knockout mice (166). These indicated that there were other compensatory factors that could make a good combination with GLP-1. Indeed for instance, GLP-1 has been identified to be one of the downstream mediators of leptin and leptin has been suggested to enhance the central GLP-1 activity (167).
The use of Ex-4 and liraglutide, two GLP-1R agonists, for treatment of diabetes produced small yet significant reductions in body weight (168-171). GLP-1 also induced weight loss after bariatric surgery (172). Dual agonism of GLP-1R/GCGR (173) and very recently triagonism with GLP-1R/GIPR/GCGR (174) have been found to have potent effects to reverse obesity in rodents. A GLP-1R agonist has also been found to have therapeutic effects on alcohol use disorders in mice (175). With these increasing therapeutic advantages, the hunt for GLP-1R agonists and combinatorial integrative effect of GLP-1 with other hormones is increasing to obtain maximum efficiency in therapeutic treatments.

\section{GROWTH HORMONE-RELEASING HORMONE}

Named after its stimulating effect of pituitary growth hormone, GHRH or growth hormone-releasing factor is a 44-amino acid hypothalamic peptide (176-179). Predominantly in the hypothalamic region, GHRH containing cell bodies are located primarily in the ARC along with the DMH and VMH $(180,181)$. It has been shown that i.p. injection of GHRH failed to alter food intake in rodents (182) while peripheral injection of chicken GHRH inhibited feeding behavior in chicks (183), suggesting the complexity of the peripheral GHRH in feeding regulation. The i.c.v. injection of GHRH stimulated food intake at doses that did not stimulate $\mathrm{GH}$ release $(182,184)$ while the i.c.v. injection of GHRH suppressed feeding behavior in rats at a higher dose (185), suggesting that not only peripheral and central GHRH could have different effects on appetite control but different doses of GHRH might also cause different feeding behavior.

As we reviewed before (28), the cell bodies of ARC-GHRH neurons had varied projection sites with their nerve terminals being at perifornical region, lateral preoptic area and SCN/ medialpreoptic area (SCN/MPOA) (186) and mapping studies have identified SCN/MPOA as the central site of action for GHRH to induce orexigenic effects $(184,187)$. Orexigenic effect of GHRH has been found to be photoperiod sensitive which was consistent with the role of SCN/MPOA in controlling circadian rhythms (188). The i.c.v.-GHRH stimulated a dose-dependent increase and suppression of feeding during the light and dark phases of photocycle, respectively, in rats (189), and intra-SCN/ MPOA-injected GHRH antiserum reduced dark onset feeding (190) with selective suppression of protein intake (191). Collectively, these reports suggested a role of endogenous GHRH in the regulation of circadian feeding rhythm. GHRH action was found to stimulate protein intake with no effects on carbohydrate intake (192). The observation that intra-ARC injected morphine stimulated protein intake was reversed by intra-SCN/MPOA pretreatments with GHRH antiserum (193), further confirming the significant role of GHRH in the regulation of protein intake. Additionally, Intra-PVN injection of opiate antagonist inhibited the effect of i.c.v.- (194) and SCN/MPOA-injected GHRH (192) suggesting a role of opiates in GHRH-induced feeding behavior. Transcriptional profiling of hypothalamic glucose-sensing neurons along with electrophysiological studies has revealed that hypoglycemia activated GHRH neurons (195). The electrical 
patterns that controlled the hypothalamic GHRH neurons have remained elusive while recently somatostatin has been found to bring about irregular suppression of the neuronal activity of GHRH neurons (196). In summary, it is the important role in GH secretion along with its involvement in nutritional and circadian feeding behavior that has made GHRH vital in integration and coordination of diverse aspects related to metabolism, growth and nutrient regulation $(190,197)$.

\section{OTHER PEPTIDES}

Other peptides from SCT family also shared a certain degree of functional similarities on the feeding behavior. Derived from the PPG, GLP-2 was known to have anorectic effect $(198,199)$. Central but not peripheral injection of GLP-2 reduced food intake and stimulated c-Fos expression in the ARC, PVN, DMH, $\mathrm{VMH}$, and LH (200). The anorectic effect by central GLP-2R

TABLE 1 | Secretin (SCT), pituitary adenylate cyclase-activating peptide (PACAP), and glucagon (GCG) family of peptides in neural regulation of appetite

\begin{tabular}{|c|c|c|c|c|}
\hline Peptide & $\begin{array}{l}\text { Primary physiological } \\
\text { function }\end{array}$ & $\begin{array}{l}\text { Effect on } \\
\text { feeding } \\
\text { behavior }\end{array}$ & Central site of action & Central mode of action \\
\hline SCT & $\begin{array}{l}\text { Stimulates bicarbonate } \\
\text { release from pancreas } \\
\text { and water homeostasis } \\
\text { regulation }\end{array}$ & Anorectic & $\begin{array}{l}\text { - Hypothalamus: ARC and } \\
\text { PVN } \\
\text { - Brainstem: NTS } \\
\text { - Amygdala: CeA }\end{array}$ & $\begin{array}{l}\text { - Activates oxytoxinergic pathway from the dpPVN to the NTS } \\
\text { - Stimulates POMC neurons in ARC } \\
\text { - Activates melanocortin system in PVN } \\
\text { - Modulates spontaneous firing of CeA neurons }\end{array}$ \\
\hline PACAP & $\begin{array}{l}\text { Strong modulator } \\
\text { of hypothalamic } \\
\text { magnocellular neurons }\end{array}$ & Anorectic & $\begin{array}{l}\text { - Hypothalamus: } \\
\text { ARC, PVN, NAc } \\
\text { and ventromedial } \\
\text { hypothalamus (VMH) }\end{array}$ & $\begin{array}{l}\text { - Stimulates POMC neurons of ARC and activates melanocortin system } \\
\text { through MC4R in PVN } \\
\text { - Increases ARC-POMC expression by intra-VMH administration and } \\
\text { acts through glutamatergic signaling via NMDA receptors in VMH } \\
\text { - Acts through excitatory PACAPergic afferents originating within the } \\
\text { PVN to AgRP/NPY neurons of ARC activating NPY neurons (possibly } \\
\text { orexigenic effect) } \\
\text { - In NAc, mimics actions of GABA and reduces hedonic but not } \\
\text { - } \text { homeostatic feeding } \\
\text { feeding }\end{array}$ \\
\hline
\end{tabular}

\begin{tabular}{|c|c|c|c|c|}
\hline $\begin{array}{l}\text { Vasoactive intestinal } \\
\text { peptide }\end{array}$ & $\begin{array}{l}\text { Vasodilation and } \\
\text { hypotesion }\end{array}$ & Not clear & $\begin{array}{l}\text { - Hypothalamus: PVN and } \\
\text { SCN }\end{array}$ & - Stimulates HPA axis and melanocortin system \\
\hline GCG & Induces glucose release & Anorectic & $\begin{array}{l}\text { - Hypothalamus: ARC, LH } \\
\text { - Brainstem: DVC }\end{array}$ & $\begin{array}{l}\text { - Acts through GCGR-dependent PKA-Erk1/2-KATPSignaling cascade } \\
\text { in DVC } \\
\text { - Stimulates HPA axis } \\
\text { - Acts through PKA/AMPK/CaMKK } \beta \text {-dependent pathways and reduces } \\
\text { AgRP in ARC }\end{array}$ \\
\hline $\begin{array}{l}\text { GCG-like peptide-1 } \\
\text { (GLP-1) }\end{array}$ & Incretin & Anorectic & $\begin{array}{l}\text { - } \text { Hypothalamus: PVN, } \\
\text { - } \text { Brainstem: LH, DMH, and VMH } \\
\text { IPBN as well as AP, DMV } \\
\text { - } \text { Mesolimbic reward } \\
\text { system: VTA and NAc } \\
\text { - } \text { Amygdala: CeA } \\
\text { - } \text { Hippocampus: vHP }\end{array}$ & $\begin{array}{l}\text { - } \text { Activates NTS via vagal to NTS glutamatergic signaling } \\
\text { - } \text { Stimulates HPA axis in PVN } \\
\text { - } \text { - } \text { Reduces CTA in CeA } \\
\text { - } \text { Acts through NTS to IPBN circuit to activate IPBN leading to reduced } \\
\text { ingestion of palatable food and motivation to work for it in IPBN } \\
\text { - Reduces reward-motivated intake of palatable food, alcohol and } \\
\text { - } \text { - } \text { Acts in NAc core neurons through GLP-1R activation via presynaptic, } \\
\text { - AMPA/kainate-mediated glutamatergic mechanism } \\
\text { - } \text { Acts through VTA to amygdala dopamine circuit } \\
\text { Reduces feeding and high-fat palatable food in VHP }\end{array}$ \\
\hline
\end{tabular}

\begin{tabular}{|c|c|c|c|c|}
\hline $\begin{array}{l}\text { GCG-like peptide-2 } \\
\text { (GLP-2) }\end{array}$ & Intestinal function & Anorectic & - Hypothalamus: ARC & - Stimulates POMC and activates melanocortin pathway \\
\hline $\begin{array}{l}\text { Growth hormone- } \\
\text { releasing hormone }\end{array}$ & Growth hormone release & Orexigenic & $\begin{array}{l}\text { - Hypothalamus: ARC, } \\
\text { DMH, SCN/MPOA }\end{array}$ & $\begin{array}{l}\text { - Participates SCN/MPOA mediated circadian feeding stimulation } \\
\text { - Stimulates protein intake } \\
\text { - Induces opiate-involved feeding behavior }\end{array}$ \\
\hline $\begin{array}{l}\text { Peptide histidine } \\
\text { isoleucine }\end{array}$ & Prolactin regulation & Anorectic & $\begin{array}{l}\text { - Hypothalamus: PVN } \\
\text { - Amygdala: CeA }\end{array}$ & $\begin{array}{l}\text { - Acts through oxytocin/vasopressin system in PVN and activates PVN } \\
\text { OT neurons by intra-CeA infusion }\end{array}$ \\
\hline
\end{tabular}

ARC, arcuate nucleus; PVN, paraventricular nucleus; NTS, nucleus tractus solitarius; CeA, central amygdala; POMC, pro-opiomelanocortin; dpPVN, dorsal division of the parvocellular PVN; VMH, ventromedial hypothalamus; MC4R, melanocortin-4 receptor; AgRP, agouti gene-related protein; NPY, neuropeptide Y; SCN, suprachiasmatic nucleus; HPA axis, hypothalamic-pituitary-adrenal axis; LH, lateral hypothalamus; DVC, dorsal vagal complex; AMPK, AMP-activated protein kinase; CaMKK $\beta$, Ca ${ }^{2+}$-calmodulin-dependent protein kinase kinase $\beta ; D M H$, dorsomedial hypothalamus; IPBN, lateral parabrachial nucleus; AP, area postrema; DMV, dorsal motor nucleus of the vagus; VTA, ventral tegmental area; NAc, nucleus accumbens; vHP, ventral hippocampus; CTA, conditioned taste aversion; MPOA, medialpreoptic area. 
activation was reversed in MC4R knockout mice suggesting the involvement of melanocortin system and specific deletion of GLP-2R in the ARC POMC neurons resulted in increased intake (199).

Unlike its incretin counterpart GLP-1, GIP alleviated obesity through increased energy expenditure but did not affect food intake (201-203). However, recent evidences have shown the modulation of hypothalamic gene expression by i.c.v.-GIP (204). The i.c.v. administration and intra-PVN or -CeA injection of PHI decreased food consumption in overnight-deprived rats (205). These peptides' roles in appetite regulation has not been well understood, hence further research is warranted for clarity in understanding the role of these peptides in neuromodulation of feeding behavior.

\section{CONCLUSION}

This review has focused on central roles of the SCT, PACAP and GCG family of peptides in regulating food intake behavior. With members of the family such as GLP-1 exhibiting significant therapeutic advantage, SCT family of peptides have been considered as an important group of hormones in neural appetite modulation. With the exception of GHRH which is an orexigenic peptide, members of the SCT family of peptides mostly exhibit anorectic roles with GLP-1 and PACAP being most-studied among all the peptides. Central sites of action, effects on specific aspect of feeding behavior control, and the central circuitry recruited to carry out these effects vary widely among the SCT family of peptides and they have been summarized in Table 1. More information on the site-specific endogenous actions of these peptides on food intake modulation and the neural pathways involved along with the mechanistic insights is still unclear. Of the neural circuitry involved, melanocortin system (206), stimulated mainly through activation of POMC neurons, is the most common neural pathway through which these peptides, at least partially, exert their anorectic effect. Yet, the combinatorial effect of these peptides, along with the mechanisms and the neural pathways involved in such a scenario, is important to understand if they have synergistic additive effects on food intake reduction. Importance of this research is clearly evident as a novel monomeric peptide triagonist acting on GLP-1, GIP, and GCG receptors (174) has been found to be the most effective among existing pharmacological agonists/strategies in reversing obesity in mice $(207,208)$.

\section{REFERENCES}

1. Cardoso JC, Vieira FA, Gomes AS, Power DM. The serendipitous origin of chordate secretin peptide family members. BMC Evol Biol (2010) 10(1):135. doi:10.1186/1471-2148-10-135

2. Lee VHY, Lee LTO, Chu JYS, Lam IPY, Siu FKY, Vaudry H, et al. An indispensable role of secretin in mediating the osmoregulatory functions of angiotensin II. FASEB J (2010) 24(12):5024-32. doi:10.1096/f.10-165399

3. Laburthe M, Couvineau A, Gaudin P, Maoret JJ, Rouyer-Fessard C, Nicole P. Receptors for VIP, PACAP, secretin, GRF, glucagon, GLP-1, and other members of their new family of g protein-linked receptors: structure-function relationship with special reference to the human VIP-1 receptora.
Recent research on the neurobiology of food intake behavior has taken a leap with the advances in neuro-technology for mapping, manipulating, and monitoring molecularly defined cell types that are exponentially expanding our understanding into appetite modulating neural circuits (209). Although there is a huge gap between our current knowledge of the SCT family peptides and valuable clinical implications of these peptides for disease treatment, significance on the clinical applications of these peptides has already been evident by the significant therapeutic advantage by GLP-1R agonists in human $(210,211)$. In overweight or obese individuals, GLP-1R agonists have been shown to produce clinically relevant reductions in weight, body mass index, and waist circumference $(212,213)$. Liraglutide $3.0 \mathrm{mg} \mathrm{day}^{-1}$ has been approved for weight management in the US on December 23, 2014 (214), and in the EU on March 23, 2015 (215). Novel combinatorial hormone therapies are being researched at the pre-clinical stage for obesity treatment (216), wherein the novel unimolecular GLP-1R/GIPR/GCGR triagonist at a very low dose of $2 \mathrm{nmol} / \mathrm{kg}$ decreases cumulative food intake and reduces the body weight of HFD-mice by $18.3 \%$ and is more effective than any other available therapy (174). While the application prospect of SCT family peptides is exciting, some aversive consequences brought by injection of these peptides should not be easily ignored. Further regional and functional specific research as well as the understanding on combinational effects of SCT family peptides needs to be greatly enhanced. Future studies with the new tools that give neurobiologists opportunity to rigorously examine neural circuits in modulating feeding behavior should provide insights and novel therapeutic approaches to combat pathophysiological conditions related to appetite disorders and obesity.

\section{AUTHOR CONTRIBUTIONS}

RS contributed to manuscript preparation and manuscript definition of intellectual content. LW also contributed to manuscript preparation and followed by manuscript editing and revision. These two authors contributed equally to this work and should be listed as co-authors. BC, as the corresponding author, approved the final version of the manuscript.

\section{ACKNOWLEDGMENTS}

This work was supported by HK government RGC Grant GRF 17105514; HKU6/CRF/11G to BC.

Ann N Y Acad Sci (1996) 805(1):94-109. doi:10.1111/j.1749-6632.1996. tb17476.x

4. Harmar AJ. Family-B G-protein-coupled receptors. Genome Biol (2001) 2(12):3011-3. doi:10.1186/gb-2001-2-12-reviews3013

5. Archbold JK, Flanagan JU, Watkins HA, Gingell JJ, Hay DL. Structural insights into RAMP modification of secretin family G protein-coupled receptors: implications for drug development. Trends Pharmacol Sci (2011) 32(10):591-600. doi:10.1016/j.tips.2011.05.007

6. Furness SGB, Wootten D, Christopoulos A, Sexton PM. Consequences of splice variation on secretin family $G$ protein-coupled receptor function. Br J Pharmacol (2012) 166(1):98-109. doi:10.1111/j.1476-5381.2011. 01571.x 
7. Poyner DR, Hay DL. Secretin family (Class B) G protein-coupled receptors from molecular to clinical perspectives. Br J Pharmacol (2012) 166(1):1-3. doi:10.1111/j.1476-5381.2011.01810.x

8. Watkins HA, Au M, Hay DL. The structure of secretin family GPCR peptide ligands: implications for receptor pharmacology and drug development. Drug Discov Today (2012) 17(17-18):1006-14. doi:10.1016/j. drudis.2012.05.005

9. Saper CB, Chou TC, Elmquist JK. The need to feed: homeostatic and hedonic control of eating. Neuron (2002) 36(2):199-211. doi:10.1016/ S0896-6273(02)00969-8

10. Grill HJ, Kaplan JM. The neuroanatomical axis for control of energy balance. Front Neuroendocrinol (2002) 23(1):2-40. doi:10.1006/frne.2001.0224

11. Cone RD. Anatomy and regulation of the central melanocortin system. Nat Neurosci (2005) 8(5):571-8. doi:10.1038/nn1455

12. Williams G, Bing C, Cai XJ, Harrold JA, King PJ, Liu XH. The hypothalamus and the control of energy homeostasis: different circuits, different purposes. Physiol Behav (2001) 74(4-5):683. doi:10.1016/S0031-9384(01)00612-6

13. Leibowitz SF, Wortley KE. Hypothalamic control of energy balance: different peptides, different functions. Peptides (2004) 25(3):473-504. doi:10.1016/j. peptides.2004.02.006

14. Morton GJ, Cummings DE, Baskin DG, Barsh GS, Schwartz MW. Central nervous system control of food intake and body weight. Nature (2006) 443(7109):289-95. doi:10.1038/nature05026

15. Lopaschuk GD, Ussher JR, Jaswal JS. Targeting intermediary metabolism in the hypothalamus as a mechanism to regulate appetite. Pharmacol Rev (2010) 62(2):237-64. doi:10.1124/pr.109.002428

16. Dietrich MO, Horvath TL. Hypothalamic control of energy balance: insights into the role of synaptic plasticity. Trends Neurosci (2013) 36(2):65-73. doi:10.1016/j.tins.2012.12.005

17. Kristensen P, Judge ME, Thim L, Ribel U, Christjansen KN, Wulff BS, et al. Hypothalamic CART is a new anorectic peptide regulated by leptin. Nature (1998) 393(6680):72-6. doi:10.1038/29993

18. Vrang N, Tang-Christensen M, Larsen PJ, Kristensen P. Recombinant CART peptide induces c-Fos expression in central areas involved in control of feeding behaviour. Brain Res (1999) 818(2):499-509. doi:10.1016/ S0006-8993(98)01349-3

19. Volkoff H, Peter RE. Effects of CART peptides on food consumption, feeding and associated behaviors in the goldfish, Carassius auratus: actions on neuropeptide Y-and orexin A-induced feeding. Brain Res (2000) 887(1):125-33. doi:10.1016/S0006-8993(00)03001-8

20. Burdakov D, Luckman SM, Verkhratsky A. Glucose-sensing neurons of the hypothalamus. Phil Trans Biol Sci (2005) 360(1464):2227-35. doi:10.1098/ rstb.2005.1763

21. Ahima RS, Antwi DA. Brain regulation of appetite and satiety. Endocrinol Metab Clin North Am (2008) 37(4):811-23. doi:10.1016/j.ecl.2008.08.005

22. Thorens B. Sensing of glucose in the brain. Handb Exp Pharmacol (2012) 209:277-94. doi:10.1007/978-3-642-24716-3_12

23. Travagli RA, Hermann GE, Browning KN, Rogers RC. Musings on the wanderer: what's new in our understanding of vago-vagal reflexes? III. Activity-dependent plasticity in vago-vagal reflexes controlling the stomach. Am J Physiol Gastrointest Liver Physiol (2003) 284(2):G180. doi:10.1152/ ajpgi.00413.2002

24. Morton GJ, Blevins JE, Williams DL, Niswender KD, Gelling RW, Rhodes CJ, et al. Leptin action in the forebrain regulates the hindbrain response to satiety signals. J Clin Invest (2005) 115(3):703-10. doi:10.1172/JCI200522081

25. Wise RA. Role of brain dopamine in food reward and reinforcement. Philos Trans R Soc Lond B Biol Sci (2006) 361(1471):1149-58. doi:10.1098/ rstb.2006.1854

26. Petrovich GD, Holland PC, Gallagher M. Amygdalar and prefrontal pathways to the lateral hypothalamus are activated by a learned cue that stimulates eating. J Neurosci (2005) 25(36):8295-302. doi:10.1523/ JNEUROSCI.2480-05.2005

27. de Lecea L, Kilduff T, Peyron C, Gao X-B, Foye P, Danielson P, et al. The hypocretins: hypothalamus-specific peptides with neuroexcitatory activity. Proc Natl Acad Sci U S A (1998) 95(1):322-7. doi:10.1073/pnas.95.1.322

28. Sekar R, Chow BKC. Role of secretin peptide family and their receptors in the hypothalamic control of energy homeostasis. Horm Metab Res (2013) 45(13):945-54. doi:10.1055/s-0033-1353155
29. Dogrukol-Ak D, Tore F, Tuncel N. Passage of VIP/PACAP/secretin family across the blood-brain barrier: therapeutic effects. Curr Pharm Des (2004) 10(12):1325-40. doi:10.2174/1381612043384934

30. Bayliss WM, Starling EH. The mechanism of pancreatic secretion. J Physiol (1902) 28(5):325-53. doi:10.1113/jphysiol.1902.sp000920

31. Lam IPY, Siu FKY, Chu JYS, Chow BKC. Multiple actions of secretin in the human body. Int Rev Cytol (2008) 265:159-90. doi:10.1016/ S0074-7696(07)65004-9

32. Ng SSM, Yung WH, Chow BKC. Secretin as a neuropeptide. Mol Neurobiol (2002) 26(1):97-107. doi:10.1385/MN:26:1:097

33. Chey WY, Chang T-M. Secretin, 100 years later. J Gastroenterol (2003) 38(11):1025-35. doi:10.1007/s00535-003-1235-3

34. Chu JYS, Yung WH, Chow BKC. Endogenous release of secretin from the hypothalamus. Ann N Y Acad Sci (2006) 1070:196-200. doi:10.1196/ annals.1317.012

35. Chu JYS, Yung WH, Chow BKC. Secretin: a pleiotrophic hormone. Ann N Y Acad Sci (2006) 1070(1):27-50. doi:10.1196/annals.1317.013

36. Chu JYS, Lee LTO, Lai CH, Vaudry H, Chan YS, Yung WH, et al. Secretin as a neurohypophysial factor regulating body water homeostasis. Proc Natl Acad Sci U S A (2009) 106(37):15961-6. doi:10.1073/pnas.0903695106

37. Welch MG, Keune JD, Welch-Horan TB, Anwar N, Anwar M, Ludwig RJ, et al. Secretin: hypothalamic distribution and hypothesized neuroregulatory role in autism. Cell Mol Neurobiol (2004) 24(2):219-41. doi:10.1023/B:CEMN.0000018618.59015.a2

38. Yang H, Wang L, Wu SV, Tay J, Goulet M, Boismenu R, et al. Peripheral secretin-induced Fos expression in the rat brain is largely vagal dependent. Neuroscience (2004) 128(1):131-41. doi:10.1016/j.neuroscience.2004.06.027

39. Cheng CYY, Chu JYS, Chow BKC. Central and peripheral administration of secretin inhibits food intake in mice through the activation of the melanocortin system. Neuropsychopharmacology (2011) 36(2):459-71. doi:10.1038/npp. 2010.178

40. Glick Z, Thomas DW, Mayer J. Absence of effect of injections of the intestinal hormones secretin and cholecystokinin-pancreozymin upon feeding behavior. Physiol Behav (1971) 6(1):5-8. doi:10.1016/0031-9384(71)90004-7

41. Gibbs J, Young RC, Smith GP. Cholecystokinin decreases food intake in rats. J Comp Physiol Psychol (1973) 84(3):488-95. doi:10.1037/h0034870

42. Lorenz DN, Kreielsheimer G, Smith GP. Effect of cholecystokinin, gastrin, secretin and GIP on sham feeding in the rat. Physiol Behav (1979) 23(6):1065-72. doi:10.1016/0031-9384(79)90298-1

43. Banks WA, Goulet M, Rusche JR, Niehoff ML, Boismenu R. Differential transport of a secretin analog across the blood-brain and blood-cerebrospinal fluid barriers of the mouse. J Pharmacol Exp Ther (2002) 302(3):1062-9. doi:10.1124/jpet.102.036129

44. Li Y, Wu X, Yao H, Owyang C. Secretin activates vagal primary afferent neurons in the rat: evidence from electrophysiological and immunohistochemical studies. Am J Physiol Gastrointest Liver Physiol (2005) 289(4):G745-52. doi:10.1152/ajpgi.00039.2005

45. Motojima Y, Kawasaki M, Matsuura T, Saito R, Yoshimura M, Hashimoto $\mathrm{H}$, et al. Effects of peripherally administered cholecystokinin-8 and secretin on feeding/drinking and oxytocin-mRFP1 fluorescence in transgenic rats. Neurosci Res (2016) 109:63-9. doi:10.1016/j.neures.2016.02.005

46. Chu JYS, Cheng CYY, Sekar R, Chow BKC. Vagal afferent mediates the anorectic effect of peripheral secretin. PLoS One (2013) 8(5):e64859. doi:10.1371/journal.pone.0064859

47. Pang YY, Chen XY, Xue Y, Han XH, Chen L. Effects of secretin on neuronal activity and feeding behavior in central amygdala of rats. Peptides (2015) 66:1-8. doi:10.1016/j.peptides.2015.01.012

48. Miyata A, Arimura A, Dahl RR, Minamino N, Uehara A, Jiang L, et al. Isolation of a novel 38 residue-hypothalamic polypeptide which stimulates adenylate cyclase in pituitary cells. Biochem Biophys Res Commun (1989) 164(1):567-74. doi:10.1016/0006-291X(89)91757-9

49. Vaudry D, Gonzalez BJ, Basille M, Yon L, Fournier A, Vaudry H. Pituitary adenylate cyclase-activating polypeptide and its receptors: from structure to functions. Pharmacol Rev (2000) 52(2):269-324.

50. Vaudry D, Falluel-Morel A, Bourgault S, Basille M, Burel D, Wurtz O, et al. Pituitary adenylate cyclase-activating polypeptide and its receptors: 20 years after the discovery. Pharmacol Rev (2009) 61(3):283-357. doi:10.1124/ pr.109.001370 
51. Koves K, Arimura A, Gorcs TG, Somogyvari-Vigh A. Comparative distribution of immunoreactive pituitary adenylate cyclase activating polypeptide and vasoactive intestinal polypeptide in rat forebrain. Neuroendocrinology (1991) 54(2):159-69. doi:10.1159/000125864

52. Dürr K, Norsted E, Gömüç B, Suarez E, Hannibal J, Meister B. Presence of pituitary adenylate cyclase-activating polypeptide (PACAP) defines a subpopulation of hypothalamic POMC neurons. Brain Res (2007) 1186(0):203-11. doi:10.1016/j.brainres.2007.10.015

53. Mounien L, Bizet P, Boutelet I, Gourcerol G, Basille M, Gonzalez B, et al. Expression of PACAP receptor mRNAs by neuropeptide $\mathrm{Y}$ neurons in the rat arcuate nucleus. Ann N Y Acad Sci (2006) 1070(1):457-61. doi:10.1196/ annals.1317.061

54. Mounien L, Bizet P, Boutelet I, Gourcerol G, Fournier A, Vaudry H, et al. Pituitary adenylate cyclase-activating polypeptide directly modulates the activity of proopiomelanocortin neurons in the rat arcuate nucleus. Neuroscience (2006) 143(1):155-63. doi:10.1016/j.neuroscience.2006.07.022

55. Morley JE, Horowitz M, Morley PM, Flood JF. Pituitary adenylate cyclase activating polypeptide (PACAP) reduces food intake in mice. Peptides (1992) 13(6):1133-5. doi:10.1016/0196-9781(92)90019-Y

56. Chance WT, Thompson H, Thomas I, Fischer JE. Anorectic and neurochemical effects of pituitary adenylate cyclase activating polypeptide in rats. Peptides (1995) 16(8):1511-6. doi:10.1016/0196-9781(95)02048-9

57. Mounien L, Do Rego J-C, Bizet P, Boutelet I, Gourcerol G, Fournier A, et al. Pituitary adenylate cyclase-activating polypeptide inhibits food intake in mice through activation of the hypothalamic melanocortin system. Neuropsychopharmacology (2009) 34(2):424-35. doi:10.1038/npp.2008.73

58. Mizuno Y, Kondo K, Terashima Y, Arima H, Murase T, Oiso Y. Anorectic effect of pituitary adenylate cyclase activating polypeptide (PACAP) in rats: lack of evidence for involvement of hypothalamic neuropeptide gene expression. J Neuroendocrinol (1998) 10(8):611-6. doi:10.1046/j.13652826.1998.00244.x

59. Aoki Y, Iwasaki Y, Katahira M, Oiso Y, Saito H. Regulation of the rat proopiomelanocortin gene expression in AtT-20 cells. II: effects of the pituitary adenylate cyclase-activating polypeptide and vasoactive intestinal polypeptide. Endocrinology (1997) 138(5):1930-4. doi:10.1210/ endo.138.5.5116

60. Resch JM, Maunze B, Gerhardt AK, Magnuson SK, Phillips KA, Choi S. Intrahypothalamic pituitary adenylate cyclase-activating polypeptide regulates energy balance via site-specific actions on feeding and metabolism. Am J Physiol Endocrinol Metab (2013) 305(12):E1452. doi:10.1152/ ajpendo.00293.2013

61. Choi S, Dallman MF. Hypothalamic obesity: multiple routes mediated by loss of function in medial cell groups. Endocrinology (1999) 140(9):4081-8. doi:10.1210/en.140.9.4081

62. Resch JM, Boisvert JP, Hourigan AE, Mueller CR, Yi SS, Choi S. Stimulation of the hypothalamic ventromedial nuclei by pituitary adenylate cyclase-activating polypeptide induces hypophagia and thermogenesis. Am J Physiol Regul Integr Comp Physiol (2011) 301(6):R1625-34. doi:10.1152/ ajpregu.00334.2011

63. Macdonald D, Weerapura M, Beazely M, Martin L, Czerwinski W, Roder J, et al. Modulation of NMDA receptors by pituitary adenylate cyclase activating peptide in CA1 neurons requires Goq, protein kinase C, and activation of Src. J Neurosci (2005) 25(49):11374-84. doi:10.1523/ JNEUROSCI.3871-05.2005

64. Toda AM, Huganir RL. Regulation of AMPA receptor phosphorylation by the neuropeptide PACAP38. Proc Natl Acad Sci US A (2015) 112(21):6712-7. doi:10.1073/pnas.1507229112

65. Resch JM, Maunze B, Phillips KA, Choi S. Inhibition of food intake by PACAP in the hypothalamic ventromedial nuclei is mediated by NMDA receptors. Physiol Behav (2014) 133:230-5. doi:10.1016/j.physbeh.2014. 05.029

66. Hurley MM, Maunze B, Block ME, Frenkel MM, Reilly MJ, Kim E, et al. Pituitary adenylate-cyclase activating polypeptide regulates hunger-and palatability-induced binge eating. Front Neurosci (2016) 10:383. doi:10.3389/ fnins.2016.00383

67. Hawke Z, Ivanov TR, Bechtold DA, Dhillon H, Lowell BB, Luckman SM. PACAP neurons in the hypothalamic ventromedial nucleus are targets of central leptin signaling. J Neurosci (2009) 29(47):14828-35. doi:10.1523/ JNEUROSCI.1526-09.2009
68. Krashes MJ, Shah BP, Madara JC, Olson DP, Strochlic DE, Garfield AS, et al. An excitatory paraventricular nucleus to AgRP neuron circuit that drives hunger. Nature (2014) 507(7491):238-42. doi:10.1038/nature12956

69. Nakata M, Kohno D, Shintani N, Nemoto Y, Hashimoto H, Baba A, et al. PACAP deficient mice display reduced carbohydrate intake and PACAP activates NPY-containing neurons in the rat hypothalamic arcuate nucleus. Neurosci Lett (2004) 370(2-3):252-6. doi:10.1016/j.neulet.2004.08.034

70. Rudecki AP, Gray SL. PACAP in the defense of energy homeostasis. Trends Endocrinol Metab (2016) 27(9):620-32. doi:10.1016/j.tem.2016.04.008

71. Hannibal J, Georg B, Fahrenkrug J. Altered circadian food anticipatory activity rhythms in PACAP receptor 1 (PAC1) deficient mice. PLoS One (2016) 11(1):e0146981. doi:10.1371/journal.pone.0146981

72. Yi CX, Sun N, Ackermans MT, Alkemade A, Foppen E, Shi J, et al. Pituitary adenylate cyclase-activating polypeptide stimulates glucose production via the hepatic sympathetic innervation in rats. Diabetes (2010) 59(7):1591-600. doi:10.2337/db09-1398

73. Grinevich V, Fournier A, Pelletier G. Effects of pituitary adenylate cyclaseactivating polypeptide (PACAP) on corticotropin-releasing hormone $(\mathrm{CRH})$ gene expression in the rat hypothalamic paraventricular nucleus. Brain Res (1997) 773(1):190-6. doi:10.1016/S0006-8993(97)01011-1

74. Kageyama K, Hanada K, Iwasaki Y, Sakihara S, Nigawara T, Kasckow J, et al. Pituitary adenylate cyclase-activating polypeptide stimulates corticotropin-releasing factor, vasopressin and interleukin- 6 gene transcription in hypothalamic 4B cells. J Endocrinol (2007) 195(2):199-211. doi:10.1677/ JOE-07-0125

75. Tachibana T, Saito E-S, Takahashi H, Saito S, Tomonaga S, Boswell T, et al. Anorexigenic effects of pituitary adenylate cyclase-activating polypeptide and vasoactive intestinal peptide in the chick brain are mediated by corticotrophin-releasing factor. Regul Pept (2004) 120(1):99-105. doi:10.1016/j. regpep.2004.02.016

76. Maruyama K, Miura T, Uchiyama M, Shioda S, Matsuda K. Relationship between anorexigenic action of pituitary adenylate cyclase-activating polypeptide (PACAP) and that of corticotropin-releasing hormone $(\mathrm{CRH})$ in the goldfish, Carassius auratus. Peptides (2006) 27(7):1820-6. doi:10.1016/j. peptides.2006.01.013

77. Kang KS, Shimizu K, Azuma M, Ui Y, Nakamura K, Uchiyama M, et al. Gonadotropin-releasing hormone II (GnRH II) mediates the anorexigenic actions of $\alpha$-melanocyte-stimulating hormone ( $\alpha-\mathrm{MSH})$ and corticotropin-releasing hormone (CRH) in goldfish. Peptides (2011) 32(1):31-5. doi:10.1016/j.peptides.2010.10.013

78. Vu JP, Goyal D, Luong L, Oh S, Sandhu R, Norris J, et al. PACAP intraperitoneal treatment suppresses appetite and food intake via PAC1 receptor in mice by inhibiting ghrelin and increasing GLP-1 and leptin. Am J Physiol Gastrointest Liver Physiol (2015) 309(10):G816. doi:10.1152/ ajpgi.00190.2015

79. Vu JP, Larauche M, Flores M, Luong L, Norris J, Oh S, et al. Regulation of appetite, body composition, and metabolic hormones by vasoactive intestinal polypeptide (VIP). J Mol Neurosci (2015) 56(2):377-87. doi:10.1007/ s12031-015-0556-z

80. Said SI, Mutt V. Polypeptide with broad biological activity: isolation from small intestine. Science (1970) 169(3951):1217-8. doi:10.1126/ science.169.3951.1217

81. Said SI, Mutt V. Isolation from porcine-intestinal wall of a vasoactive octacosapeptide related to secretin and to glucagon. Eur J Biochem (1972) 28(2):199-204. doi:10.1111/j.1432-1033.1972.tb01903.x

82. Fuxe K, Hökfelt T, Said SI, Mutt V. Vasoactive intestinal polypeptide and the nervous system: immunohistochemical evidence for localization in central and peripheral neurons, particularly intracortical neurons of the cerebral cortex. Neurosci Lett (1977) 5(5):241-6. doi:10.1016/0304-3940(77) 90073-8

83. Dussaillant M, Sarrieau A, Gozes I, Berod A, Rostene W. Distribution of cells expressing vasoactive intestinal peptide/peptide histidine isoleucine-amide precursor messenger rna in the rat brain. Neuroscience (1992) 50(3):519-30. doi:10.1016/0306-4522(92)90444-7

84. Usdin TB, Bonner TI, Mezey E. Two receptors for vasoactive intestinal polypeptide with similar specificity and complementary distributions. Endocrinology (1994) 135(6):2662-80. doi:10.1210/endo.135.6.7988457

85. Pedersen-Bjergaard U, Host U, Kelbaek H, Schifter S, Rehfeld JF, Faber J, et al. Influence of meal composition on postprandial peripheral plasma 
concentrations of vasoactive peptides in man. Scand J Clin Lab Invest (1996) 56(6):497-503. doi:10.3109/00365519609088805

86. Jozsa R, Nemeth J, Tamas A, Hollosy T, Lubics A, Jakab B, et al. Shortterm fasting differentially alters PACAP and VIP levels in the brains of rat and chicken. Ann N Y Acad Sci (2006) 1070:354. doi:10.1196/annals. 1317.044

87. Tachibana T, Saito S, Tomonaga S, Takagi T, Saito E-S, Boswell T, et al. Intracerebroventricular injection of vasoactive intestinal peptide and pituitary adenylate cyclase-activating polypeptide inhibits feeding in chicks. Neurosci Lett (2003) 339(3):203-6. doi:10.1016/S0304-3940(03)00017-X

88. Khan MSI, Cline MA, Aramaki T, Ueda H, Tachibana T. Feeding response following central administration of chicken vasoactive intestinal peptide in chicks. Gen Comp Endocrinol (2013) 184(0):61-6. doi:10.1016/j. ygcen.2013.01.002

89. Matsuda K, Maruyama K, Nakamachi T, Miura T, Uchiyama M, Shioda S. Inhibitory effects of pituitary adenylate cyclase-activating polypeptide (PACAP) and vasoactive intestinal peptide (VIP) on food intake in the goldfish, Carassius auratus. Peptides (2005) 26(9):1611-6. doi:10.1016/j. peptides.2005.02.022

90. Matsuda K, Maruyama K, Nakamachi T, Miura T, Shioda S. Effects of pituitary adenylate cyclase-activating polypeptide and vasoactive intestinal polypeptide on food intake and locomotor activity in the goldfish, Carassius auratus. Ann N Y Acad Sci (2006) 1070(1):417-21. doi:10.1196/ annals.1317.054

91. Ghourab S, Beale KE, Semjonous NM, Simpson KA, Martin NM, Ghatei $\mathrm{MA}$, et al. Intracerebroventricular administration of vasoactive intestinal peptide inhibits food intake. Regul Pept (2011) 172(1-3):8-15. doi:10.1016/j. regpep.2011.07.006

92. Bechtold DA, Brown TM, Luckman SM, Piggins HD. Metabolic rhythm abnormalities in mice lacking VIP-VPAC2 signaling. Am J Physiol Regul Integr Comp Physiol (2008) 294(2):R344-51. doi:10.1152/ajpregu.00667.2007

93. Alexander LD, Sander LD. Vasoactive intestinal peptide stimulates ACTH and corticosterone release after injection into the PVN. Regul Pept (1994) 51(3):221-7. doi:10.1016/0167-0115(94)90068-X

94. Alexander LD, Evans K, Sander LD. A possible involvement of VIP in feeding-induced secretion of ACTH and corticosterone in the Rat. Physiol Behav (1995) 58(2):409-13. doi:10.1016/0031-9384(95)00058-Q

95. Mighiu PI, Yue JT, Filippi BM, Abraham MA, Chari M, Lam CK, et al. Hypothalamic glucagon signaling inhibits hepatic glucose production. Nat Med (2013) 19(6):766-72. doi:10.1038/nm.3115

96. Abraham MA, Yue JT, LaPierre MP, Rutter GA, Light PE, Filippi BM, et al. Hypothalamic glucagon signals through the K ATP channels to regulate glucose production. Mol Metab (2014) 3(2):202-8. doi:10.1016/j. molmet.2013.11.007

97. Habegger KM, Heppner KM, Geary N, Bartness TJ, DiMarchi R, Tschop MH. The metabolic actions of glucagon revisited. Nat Rev Endocrinol (2010) 6(12):689-97. doi:10.1038/nrendo.2010.187

98. Jones BJ, Tan T, Bloom SR. Minireview: glucagon in stress and energy homeostasis. Endocrinology (2012) 153(3):1049-54. doi:10.1210/ en.2011-1979

99. Abraham MA, Lam TK. Glucagon action in the brain. Diabetologia (2016) 59(7):1367-71. doi:10.1007/s00125-016-3950-3

100. Schulman JL, Carleton JL, Whitney G, Whitehorn JC. Effect of glucagon on food intake and body weight in man. J Appl Physiol (1957) 11(3):419-21.

101. Penick SB, Hinkle LE Jr. Depression of food intake induced in healthy subjects by glucagon. N Engl J Med (1961) 264:893-7. doi:10.1056/ NEJM196105042641801

102. Martin JR, Novin D. Decreased feeding in rats following hepatic-portal infusion of glucagon. Physiol Behav (1977) 19(4):461-6. doi:10.1016/0031-9384(77)90218-9

103. Vanderweele DA, Macrum BL, Oetting RL. Glucagon, satiety from feeding and liver/pancreatic interactions. Brain Res Bull (1986) 17(4):539-43. doi:10.1016/0361-9230(86)90223-6

104. Geary N, Smith GP. Pancreatic glucagon and postprandial satiety in the rat. Physiol Behav (1982) 28(2):313-22. doi:10.1016/0031-9384(82)90081-6

105. Geary N, Kissileff HR, Pi-Sunyer FX, Hinton V. Individual, but not simultaneous, glucagon and cholecystokinin infusions inhibit feeding in men. Am J Physiol Regul Integr Comp Physiol (1992) 262(6):R975-80.
106. Geary N, Smith GP. Selective hepatic vagotomy blocks pancreatic glucagon's satiety effect. Physiol Behav (1983) 31(3):391-4. doi:10.1016/0031-9384(83)90207-X

107. Parker JA, McCullough KA, Field BC, Minnion JS, Martin NM, Ghatei MA, et al. Glucagon and GLP-1 inhibit food intake and increase c-fos expression in similar appetite regulating centres in the brainstem and amygdala. Int J Obes (2013) 37(10):1391-8. doi:10.1038/ijo.2012.227

108. Hoosein NM, Gurd RS. Identification of glucagon receptors in rat brain. Proc Natl Acad Sci U S A (1984) 81(14):4368-72. doi:10.1073/pnas.81.14.4368

109. Lapierre MP, Abraham MA, Yue JT, Filippi BM, Lam TK. Glucagon signalling in the dorsal vagal complex is sufficient and necessary for high-protein feeding to regulate glucose homeostasis in vivo. EMBO Rep (2015) 16(10):1299-307. doi:10.15252/embr.201540492

110. Inokuchi A, Oomura Y, Shimizu N, Yamamoto T. Central action of glucagon in rat hypothalamus. Am J Physiol Regul Integr Comp Physiol (1986) 250(1):R120-6.

111. Hell N, Timo-Iaria C. Increase of food intake induced by glucagon in the rat. Physiol Behav (1985) 34(1):39-44. doi:10.1016/0031-9384(85)90074-5

112. Inokuchi A, Oomura Y, Nishimura H. Effect of intracerebroventricularly infused glucagon on feeding behavior. Physiol Behav (1984) 33(3):397-400. doi:10.1016/0031-9384(84)90160-4

113. Morawska D, Sieklucka-Dziuba M, Kleinrok Z. Central action of glucagon. Pol J Pharmacol (1998) 50(2):125-33.

114. Honda K, Kamisoyama H, Saito N, Kurose Y, Sugahara K, Hasegawa S. Central administration of glucagon suppresses food intake in chicks. Neurosci Lett (2007) 416(2):198-201. doi:10.1016/j.neulet.2007.02.011

115. Honda K, Kamisoyama H, Uemura T, Yanagi T, Saito N, Kurose Y, et al. The mechanism underlying the central glucagon-induced hyperglycemia and anorexia in chicks. Comp Biochem Physiol Part A Mol Integr Physiol (2012) 163(3-4):260-4. doi:10.1016/j.cbpa.2012.08.005

116. Kurose Y, Kamisoyama H, Honda K, Azuma Y, Sugahara K, Hasegawa $S$, et al. Effects of central administration of glucagon on feed intake and endocrine responses in sheep. Anim Sci J (2009) 80(6):686-90. doi:10.1111/j.1740-0929.2009.00685.x

117. Filippi B, Abraham M, Yue J, Lam T. Insulin and glucagon signaling in the central nervous system. Rev Endocr Metab Disord (2013) 14(4):365-75. doi:10.1007/s11154-013-9258-4

118. Shimizu H, Egawa M, Yoshimatsu H, Bray GA. Glucagon injected in the lateral hypothalamus stimulates sympathetic activity and suppresses monoamine metabolism. Brain Res (1993) 630(1-2):95-100. doi:10.1016/0006-8993(93)90647-6

119. Quiñones M, Al-Massadi O, Gallego R, Fernø J, Diéguez C, López M, et al. Hypothalamic CaMKK $\beta$ mediates glucagon anorectic effect and its diet-induced resistance. Mol Metab (2015) 4(12):961-70. doi:10.1016/j. molmet.2015.09.014

120. Baggio LL, Drucker DJ. Biology of incretins: GLP-1 and GIP. Gastroenterology (2007) 132(6):2131-57. doi:10.1053/j.gastro.2007.03.054

121. Kreymann B, Ghatei M, Williams G, Bloom S. Glucagon-like peptide-1 7-36: a physiological incretin in man. Lancet (1987) 330(8571):1300-4. doi:10.1016/S0140-6736(87)91194-9

122. Holst JJ. The physiology of glucagon-like peptide 1. Physiol Rev (2007) 87(4):1409-39. doi:10.1152/physrev.00034.2006

123. Meier JJ, Gallwitz B, Schmidt WE, Nauck MA. Glucagon-like peptide 1 as a regulator of food intake and body weight: therapeutic perspectives. Eur J Pharmacol (2002) 440(2):269-79. doi:10.1016/S0014-2999(02) 01434-6

124. Hayes MR, De Jonghe BC, Kanoski SE. Role of the glucagon-like-peptide-1 receptor in the control of energy balance. Physiol Behav (2010) 100(5):503-10. doi:10.1016/j.physbeh.2010.02.029

125. Barrera JG, Sandoval DA, D'Alessio DA, Seeley RJ. GLP-1 and energy balance: an integrated model of short-term and long-term control. Nat Rev Endocrinol (2011) 7(9):507-16. doi:10.1038/nrendo.2011.77

126. Hayes MR. Neuronal and intracellular signaling pathways mediating GLP-1 energy balance and glycemic effects. Physiol Behav (2012) 106(3):413-6. doi:10.1016/j.physbeh.2012.02.017

127. Kanoski SE, Hayes MR, Skibicka KP. GLP-1 and weight loss: unraveling the diverse neural circuitry. Am J Physiol Regul Integr Comp Physiol (2016) 310(10):R885-95. doi:10.1152/ajpregu.00520.2015 
128. Punjabi M, Arnold M, Geary N, Langhans W, Pacheco-López G. Peripheral glucagon-like peptide-1 (GLP-1) and satiation. Physiol Behav (2011) 105(1):71-6. doi:10.1016/j.physbeh.2011.02.038

129. Nakabayashi H, Nishizawa M, Nakagawa A, Takeda R, Niijima A. Vagal hepatopancreatic reflex effect evoked by intraportal appearance of tGLP-1. Am J Physiol Endocrinol Metab (1996) 271(5):E808-13.

130. Steinert RE, Beglinger C, Langhans W. Intestinal GLP-1 and satiation: from man to rodents and back. Int J Obes (2016) 40(2):198-205. doi:10.1038/ ijo.2015.172

131. Kanoski SE, Fortin SM, Arnold M, Grill HJ, Hayes MR. Peripheral and central glp-1 receptor populations mediate the anorectic effects of peripherally administered glp-1 receptor agonists, liraglutide and exendin-4. Endocrinology (2011) 152(8):3103-12. doi:10.1210/en.2011-0174

132. Secher A, Jelsing J, Baquero AF, Hecksher-Sørensen J, Cowley MA, Dalbøge LS, et al. The arcuate nucleus mediates GLP-1 receptor agonist liraglutide-dependent weight loss. J Clin Invest (2014) 124(10):4473-88. doi:10.1172/JCI75276

133. Sisley S, Gutierrez-Aguilar R, Scott M, D’Alessio DA, Sandoval DA, Seeley RJ. Neuronal GLP1R mediates liraglutide's anorectic but not glucose-lowering effect. J Clin Invest (2014) 124(6):2456-63. doi:10.1172/JCI72434

134. Turton MD, O’shea D, Gunn I, Beak SA, Edwards CMB, Meeran K, et al. A role for glucagon-like peptide-1 in the central regulation of feeding. Nature (1996) 379(6560):69-72. doi:10.1038/379069a0

135. Hayes MR, Bradley L, Grill HJ. Endogenous hindbrain glucagon-like peptide-1 receptor activation contributes to the control of food intake by mediating gastric satiation signaling. Endocrinology (2009) 150(6):2654-9. doi:10.1210/en.2008-1479

136. McMahon L, Wellman P. Decreased intake of a liquid diet in nonfood-deprived rats following intra-PVN injections of GLP-1 (7-36) amide. Pharmacol Biochem Behav (1997) 58(3):673-7. doi:10.1016/S0091-3057(97) 90017-4

137. McMahon LR, Wellman PJ. PVN infusion of GLP-1-(7-36) amide suppresses feeding but does not induce aversion or alter locomotion in rats. Am J Physiol Regul Integr Comp Physiol (1998) 274(1):R23-9.

138. Williams DL. Minireview: finding the sweet spot: peripheral versus central glucagon-like peptide 1 action in feeding and glucose homeostasis. Endocrinology (2009) 150(7):2997-3001. doi:10.1210/en.2009-0220

139. Katsurada K, Maejima Y, Nakata M, Kodaira M, Suyama S, Iwasaki Y, et al. Endogenous GLP-1 acts on paraventricular nucleus to suppress feeding: projection from nucleus tractus solitarius and activation of corticotropin-releasing hormone, nesfatin-1 and oxytocin neurons. Biochem Biophys Res Commun (2014) 451(2):276-81. doi:10.1016/j.bbrc.2014.07.116

140. Kinzig KP, D’Alessio DA, Herman JP, Sakai RR, Vahl TP, Figueiredo HF, et al. CNS glucagon-like peptide- 1 receptors mediate endocrine and anxiety responses to interoceptive and psychogenic stressors. J Neurosci (2003) 23(15):6163-70.

141. Tang-Christensen M, Vrang N, Larsen PJ. Glucagon-like peptide 1(7-36) amide's central inhibition of feeding and peripheral inhibition of drinking are abolished by neonatal monosodium glutamate treatment. Diabetes (1998) 47(4):530. doi:10.2337/diabetes.47.4.530

142. Sandoval DA, Bagnol D, Woods SC, D’Alessio DA, Seeley RJ. Arcuate glucagon-like peptide 1 receptors regulate glucose homeostasis but not food intake. Diabetes (2008) 57(8):2046-54. doi:10.2337/db07-1824

143. Beiroa D, Imbernon M, Gallego R, Senra A, Herranz D, Villarroya F, et al. GLP-1 agonism stimulates brown adipose tissue thermogenesis and browning through hypothalamic AMPK. Diabetes (2014) 63(10):3346-58. doi: $10.2337 / \mathrm{db} 14-0302$

144. Schick RR, Zimmermann JP, vorm Walde T, Schusdziarra V. Glucagon-like peptide 1-(7-36) amide acts at lateral and medial hypothalamic sites to suppress feeding in rats. Am J Physiol Regul Integr Comp Physiol (2003) 284(6):R1427-35. doi:10.1152/ajpregu.00479.2002

145. Thiele TE, Van Dijk G, Campfield LA, Smith FJ, Burn P, Woods SC, et al. Central infusion of GLP-1, but not leptin, produces conditioned taste aversions in rats. Am J Physiol Regul Integr Comp Physiol (1997) 272(2):R726-30.

146. Kinzig KP, D’Alessio DA, Seeley RJ. The diverse roles of specific GLP-1 receptors in the control of food intake and the response to visceral illness. J Neurosci (2002) 22(23):10470-6.

147. Hayes MR, Skibicka KP, Grill HJ. Caudal brainstem processing is sufficient for behavioral, sympathetic, and parasympathetic responses driven by peripheral and hindbrain glucagon-like-peptide-1 receptor stimulation. Endocrinology (2008) 149(8):4059-68. doi:10.1210/en.2007-1743

148. Hisadome K, Reimann F, Gribble FM, Trapp S. Leptin directly depolarizes preproglucagon neurons in the nucleus tractus solitarius electrical properties of glucagon-like peptide 1 neurons. Diabetes (2010) 59(8):1890-8. doi: $10.2337 / \mathrm{db} 10-0128$

149. Hayes MR, Leichner TM, Zhao S, Lee GS, Chowansky A, Zimmer D, et al. Intracellular signals mediating the food intake-suppressive effects of hindbrain glucagon-like peptide-1 receptor activation. Cell Metab (2011) 13(3):320-30. doi:10.1016/j.cmet.2011.02.001

150. Kanoski SE, Rupprecht LE, Fortin SM, De Jonghe BC, Hayes MR. The role of nausea in food intake and body weight suppression by peripheral GLP-1 receptor agonists, exendin-4 and liraglutide. Neuropharmacology (2012) 62(5):1916-27. doi:10.1016/j.neuropharm.2011.12.022

151. Rinaman L. Ascending projections from the caudal visceral nucleus of the solitary tract to brain regions involved in food intake and energy expenditure. Brain Res (2010) 1350:18-34. doi:10.1016/j.brainres.2010. 03.059

152. Alhadeff AL, Baird J-P, Swick JC, Hayes MR, Grill HJ. Glucagon-like peptide-1 receptor signaling in the lateral parabrachial nucleus contributes to the control of food intake and motivation to feed. Neuropsychopharmacology (2014) 39(9):2233-43. doi:10.1038/npp.2014.74

153. Merchenthaler I, Lane M, Shughrue P. Distribution of pre-pro-glucagon and glucagon-like peptide- 1 receptor messenger RNAs in the rat central nervous system. JComp Neurol (1999) 403(2):261-80. doi:10.1002/ (SICI) 1096-9861(19990111)403:2<261::AID-CNE8>3.0.CO;2-5

154. Richard JE, Farkas I, Anesten F, Anderberg RH, Dickson SL, Gribble FM, et al. GLP-1 receptor stimulation of the lateral parabrachial nucleus reduces food intake: neuroanatomical, electrophysiological, and behavioral evidence. Endocrinology (2014) 155(11):4356-67. doi:10.1210/ en.2014-1248

155. Alhadeff AL, Rupprecht LE, Hayes MR. GLP-1 neurons in the nucleus of the solitary tract project directly to the ventral tegmental area and nucleus accumbens to control for food intake. Endocrinology (2012) 153(2):647-58. doi:10.1210/en.2011-1443

156. Dickson SL, Shirazi RH, Hansson C, Bergquist F, Nissbrandt H, Skibicka KP. The glucagon-like peptide 1 (GLP-1) analogue, exendin-4, decreases the rewarding value of food: a new role for mesolimbic GLP-1 receptors. J Neurosci (2012) 32(14):4812-20. doi:10.1523/JNEUROSCI.6326-11.2012

157. Shirazi RH, Dickson SL, Skibicka KP. Gut peptide GLP-1 and its analogue, exendin-4, decrease alcohol intake and reward. PLoS One (2013) 8(4):e61965. doi:10.1371/journal.pone.0061965

158. Sørensen G, Reddy IA, Weikop P, Graham DL, Stanwood GD, Wortwein G, et al. The glucagon-like peptide 1 (GLP-1) receptor agonist exendin-4 reduces cocaine self-administration in mice. Physiol Behav (2015) 149:262-8. doi:10.1016/j.physbeh.2015.06.013

159. Dossat AM, Lilly N, Kay K, Williams DL. Glucagon-like peptide 1 receptors in nucleus accumbens affect food intake. J Neurosci (2011) 31(41):14453-7. doi:10.1523/JNEUROSCI.3262-11.2011

160. Mietlicki-Baase EG, Ortinski PI, Reiner DJ, Sinon CG, McCutcheon JE, Pierce RC, et al. Glucagon-like peptide-1 receptor activation in the nucleus accumbens core suppresses feeding by increasing glutamatergic AMPA/kainate signaling. J Neurosci (2014) 34(20):6985-92. doi:10.1523/ JNEUROSCI.0115-14.2014

161. Anderberg RH, Anefors C, Bergquist F, Nissbrandt H, Skibicka KP. Dopamine signaling in the amygdala, increased by food ingestion and GLP-1, regulates feeding behavior. Physiol Behav (2014) 136:135-44. doi:10.1016/j.physbeh.2014.02.026

162. Mietlicki-Baase EG, Ortinski PI, Rupprecht LE, Olivos DR, Alhadeff AL, Pierce RC, et al. The food intake-suppressive effects of glucagon-like peptide-1 receptor signaling in the ventral tegmental area are mediated by AMPA/kainate receptors. Am J Physiol Endocrinol Metab (2013) 305(11):E1367-74. doi:10.1152/ajpendo.00413.2013

163. Adell A, Artigas F. The somatodendritic release of dopamine in the ventral tegmental area and its regulation by afferent transmitter systems. Neurosci Biobehav Rev (2004) 28(4):415-31. doi:10.1016/j.neubiorev.2004. 05.001

164. Hsu TM, Hahn JD, Konanur VR, Lam A, Kanoski SE. Hippocampal GLP-1 receptors influence food intake, meal size, and effort-based responding 
for food through volume transmission. Neuropsychopharmacology (2015) 40(2):327-37. doi:10.1038/npp.2014.175

165. Scrocchi LA, Brown TJ, Maclusky N, Brubaker PL, Auerbach AB, Joyner AL, et al. Glucose intolerance but normal satiety in mice with a null mutation in the glucagon-like peptide 1 receptor gene. Nat Med (1996) 2(11):1254. doi:10.1038/nm1196-1254

166. Scrocchi LA, Drucker DJ. Effects of aging and a high fat diet on body weight and glucose tolerance in glucagon-like peptide-1 receptor-/- mice. Endocrinology (1998) 139(7):3127-32. doi:10.1210/en.139.7.3127

167. Goldstone AP, Mercer JG, Gunn I, Moar KM, Edwards CMB, Rossi M, et al. Leptin interacts with glucagon-like peptide-1 neurons to reduce food intake and body weight in rodents. FEBS Lett (1997) 415(2):134-8. doi:10.1016/ S0014-5793(97)01103-4

168. Buse JB, Henry RR, Han J, Kim DD, Fineman MS, Baron AD, et al. Effects of exenatide (exendin-4) on glycemic control over 30 weeks in sulfonylurea-treated patients with type 2 diabetes. Diabetes Care (2004) 27(11):2628-35. doi:10.2337/diacare.27.11.2628

169. Kendall DM, Riddle MC, Rosenstock J, Zhuang D, Kim DD, Fineman MS, et al. Effects of exenatide (exendin-4) on glycemic control over 30 weeks in patients with type 2 diabetes treated with metformin and a sulfonylurea. Diabetes Care (2005) 28(5):1083-91. doi:10.2337/diacare.28.5.1083

170. Astrup A, Rössner S, Van Gaal L, Rissanen A, Niskanen L, Al Hakim $\mathrm{M}$, et al. Effects of liraglutide in the treatment of obesity: a randomised, double-blind, placebo-controlled study. Lancet (2009) 374(9701):1606-16. doi:10.1016/S0140-6736(09)61375-1

171. Buse JB, Rosenstock J, Sesti G, Schmidt WE, Montanya E, Brett JH, et al. Liraglutide once a day versus exenatide twice a day for type 2 diabetes: a 26-week randomised, parallel-group, multinational, open-label trial (LEAD6). Lancet (2009) 374(9683):39-47. doi:10.1016/S0140-6736(09)60659-0

172. Morínigo R, Lacy AM, Casamitjana R, Delgado S, Gomis R, Vidal J. GLP-1 and changes in glucose tolerance following gastric bypass surgery in morbidly obese subjects. Obes Surg (2006) 16(12):1594-601. doi:10.1381/096089206779319338

173. Pocai A, Carrington PE, Adams JR, Wright M, Eiermann G, Zhu L, et al. Glucagon-like peptide 1/glucagon receptor dual agonism reverses obesity in mice. Diabetes (2009) 58(10):2258-66. doi:10.2337/db09-0278

174. Finan B, Yang B, Ottaway N, Smiley DL, Ma T, Clemmensen C, et al. A rationally designed monomeric peptide triagonist corrects obesity and diabetes in rodents. Nat Med (2015) 21(1):27-36. doi:10.1038/nm.3761

175. Suchankova P, Yan J, Schwandt M, Stangl B, Caparelli E, Momenan R, et al. The glucagon-like peptide-1 receptor as a potential treatment target in alcohol use disorder: evidence from human genetic association studies and a mouse model of alcohol dependence. Transl Psychiatry (2015) 5(6):e583. doi:10.1038/tp.2015.68

176. Deuben RR, Meites J. Stimulation of pituitary growth hormone release by a hypothalamic extract in vitro. Endocrinology (1964) 74(3):408-14. doi:10.1210/endo-74-3-408

177. Krulich L, Dhariwal APS, Mccann SM. Stimulatory and inhibitory effects of purified hypothalamic extracts on growth hormone release from rat pituitary in vitro. Endocrinology (1968) 83(4):783-90. doi:10.1210/ endo-83-4-783

178. Esch F, Böhlen P, Ling N, Brazeau P, Guillemin R. Isolation and characterization of the bovine hypothalamic growth hormone releasing factor. Biochem Biophys Res Commun (1983) 117(3):772-9. doi:10.1016/0006-291X(83)91664-9

179. Brazeau P, Böhlen P, Esch F, Ling N, Wehrenberg WB, Guillemin R. Growth hormone-releasing factor from ovine and caprine hypothalamus: isolation, sequence analysis and total synthesis. Biochem Biophys Res Commun (1984) 125(2):606-14. doi:10.1016/0006-291X(84)90582-5

180. Jacobowitz DM, Schulte H, Chrousos GP, Loriaux DL. Localization of GRFlike immunoreactive neurons in the rat brain. Peptides (1983) 4(4):521-4. doi:10.1016/0196-9781(83)90058-X

181. VandePol CJ, Leidy JW Jr, Finger TE, Robbins RJ. Immunohistochemical localization of GRF-containing neurons in rat brain. Neuroendocrinology (1986) 42(2):143-7. doi:10.1159/000124265

182. Vaccarino FJ, Bloom FE, Rivier J, Vale W, Koob GF. Stimulation of food intake in rats by centrally administered hypothalamic growth hormonereleasing factor. Nature (1985) 314(6007):167-8. doi:10.1038/314167a0
183. Tachibana T, Kubo S, Islam Khan MS, Masuda K, Ukena K, Wang Y. Peripheral injection of chicken growth hormone-releasing hormone inhibits feeding behavior in chicks. J Poult Sci (2015) 53(1):29-33. doi:10.2141/ jpsa.0150087

184. Vaccarino FJ, Hayward M. Microinjections of growth hormone-releasing factor into the medial preoptic area/suprachiasmatic nucleus region of the hypothalamus stimulate food intake in rats. Regul Pept (1988) 21(1-2):21-8. doi:10.1016/0167-0115(88)90087-0

185. Imaki T, Shibasaki T, Shizume K, Masuda A, Hotta M, Kiyosawa Y, et al. The effects of free fatty acids on growth hormone (GH)-releasing hormone mediated GH secretion in man. J Clin Endocrinol Metab (1985) 60:290-5. doi:10.1210/jcem-60-2-290

186. Sawchenko PE, Swanson LW, Rivier J, Vale WW. The distribution of growth-hormone-releasing factor (GRF) immunoreactivity in the central nervous system of the rat: an immunohistochemical study using antisera directed against rat hypothalamic GRF. J Comp Neurol (1985) 237(1):100-15. doi:10.1002/cne. 902370108

187. Dickson PR, Vaccarino FJ. Characterization of feeding behavior induced by central injection of GRF. Am J Physiol Regul Integr Comp Physiol (1990) 259(3):R651-7.

188. Rusak B, Zucker I. Neural regulation of circadian rhythms. Physiol Rev (1979) 59(3):449-526.

189. Feifel D, Vaccarino FJ. Feeding effects of growth hormone-releasing factor in rats are photoperiod sensitive. Behav Neurosci (1989) 103(4):824-30. doi:10.1037/0735-7044.103.4.824

190. Vaccarino FJ, Feifel D, Rivier J, Vale W. Antagonism of central growth hormone-releasing factor activity selectively attenuates dark-onset feeding in rats. J Neurosci (1991) 11(12):3924-7.

191. Dickson PR, Feifel D, Vaccarino FJ. Blockade of endogenous GRF at dark onset selectively suppresses protein intake. Peptides (1995) 16(1):7-9. doi:10.1016/0196-9781(94)00153-W

192. Dickson PR, Vaccarino FJ. GRF-induced feeding: evidence for protein selectivity and opiate involvement. Peptides (1994) 15(8):1343-52. doi:10.1016/0196-9781(94)90107-4

193. Vaccarino FJ, Taube MR. Intra-arcuate opiate actions stimulate GRFdependent and protein-selective feeding. Peptides (1997) 18(2):197-205. doi:10.1016/S0196-9781(96)00283-5

194. Vaccarino FJ, Buckenham KE. Naloxone blockade of growth hormonereleasing factor-induced feeding. Regul Pept (1987) 18(3-4):165-71. doi:10.1016/0167-0115(87)90005-X

195. Stanley S, Domingos AI, Kelly L, Garfield A, Damanpour S, Heisler L, et al. Profiling of glucose-sensing neurons reveals that GHRH neurons are activated by hypoglycemia. Cell Metab (2013) 18(4):596-607. doi:10.1016/j. cmet.2013.09.002

196. Osterstock G, Mitutsova V, Barre A, Granier M, Fontanaud P, Chazalon $\mathrm{M}$, et al. Somatostatin triggers rhythmic electrical firing in hypothalamic GHRH neurons. Sci Rep (2016) 6:24394. doi:10.1038/srep24394

197. Feifel D, Vaccarino FJ. Growth hormone-regulatory peptides (GHRH and somatostatin) and feeding: a model for the integration of central and peripheral function. Neurosci Biobehav (1994) 18(3):421-33. doi:10.1016/0149-7634(94)90055-8

198. Tang-Christensen M, Larsen PJ, Thulesen J, Rømer J, Vrang N. The proglucagon-derived peptide, glucagon-like peptide-2, is a neurotransmitter involved in the regulation of food intake. Nat Med (2000) 6(7):802-7. doi:10.1038/77535

199. Guan X, Shi X, Li X, Chang B, Wang Y, Li D-P, et al. GLP-2 receptor in POMC neurons suppresses feeding behavior and gastric motility. Am J Physiol Endocrinol Metabol (2012) 303(7):E853-64. doi:10.1152/ajpendo.00245.2012

200. Dalvi PS, Belsham DD. Glucagon-like peptide-2 directly regulates hypothalamic neurons expressing neuropeptides linked to appetite control in vivo and in vitro. Endocrinology (2012) 153(5):2385-97. doi:10.1210/ en.2011-2089

201. Woods SC, West DB, Stein LJ, McKay LD, Lotter EC, Porte SG, et al. Peptides and the control of meal size. Diabetologia (1981) 20(3):305-13. doi:10.1007/BF00254497

202. Miyawaki K, Yamada Y, Ban N, Ihara Y, Tsukiyama K, Zhou H, et al. Inhibition of gastric inhibitory polypeptide signaling prevents obesity. Nat Med (2002) 8(7):738-42. doi:10.1038/nm727 
203. Gault VA, McClean PL, Cassidy RS, Irwin N, Flatt PR. Chemical gastric inhibitory polypeptide receptor antagonism protects against obesity, insulin resistance, glucose intolerance and associated disturbances in mice fed high-fat and cafeteria diets. Diabetologia (2007) 50(8):1752-62. doi:10.1007/ s00125-007-0710-4

204. Ambati S, Duan J, Hartzell DL, Choi Y-H, Della-Fera MA, Baile CA. GIP-dependent expression of hypothalamic genes. Physiol Res (2011) 60(6):941-50.

205. Olszewski PK, Wirth MM, Shaw TJ, Grace MK, Levine AS. Effect of peptide histidine isoleucine on consummatory behavior in rats. Am J Physiol Regul Integr Comp Physiol (2003) 284(6):R1445-53. doi:10.1152/ ajpregu.00554.2002

206. Nuzzaci D, Laderrière A, Lemoine A, Nédélec E, Pénicaud L, Rigault C, et al. Plasticity of the melanocortin system: determinants and possible consequences on food intake. Front Endocrinol (2015) 6:143. doi:10.3389/ fendo.2015.00143

207. van der Klaauw AA, Farooqi IS. The hunger genes: pathways to obesity. Cell (2015) 161(1):119-32. doi:10.1016/j.cell.2015.03.008

208. Tschöp MH, Finan B, Clemmensen C, Gelfanov V, Perez-Tilve D, Müller TD, et al. Unimolecular polypharmacy for treatment of diabetes and obesity. Cell Metab (2016) 24(1):51-62. doi:10.1016/j.cmet.2016.06.021

209. Sternson SM, Atasoy D, Betley JN, Henry FE, Xu S. An emerging technology framework for the neurobiology of appetite. Cell Metab (2016) 23(2):234-53. doi:10.1016/j.cmet.2015.12.002

210. Juris JM. GLP-1 receptor agonists for individualized treatment of type 2 diabetes mellitus. Nat Rev Endocrinol (2012) 8(12):728. doi:10.1038/ nrendo.2012.140

211. van Bloemendaal L, Ijzerman RG, ten Kulve JS, Barkhof F, Konrad RJ, Drent ML, et al. GLP-1 receptor activation modulates appetite- and reward-related brain areas in humans (Report). Diabetes (2014) 63(12):4186. doi:10.2337/ db14-0849
212. Vilsbøll T, Christensen M, Junker AE, Knop FK, Gluud LL. Effects of glucagon-like peptide-1 receptor agonists on weight loss: systematic review and meta-analyses of randomised controlled trials. BMJ (2012) 344:d7771. doi:10.1136/bmj.d7771

213. Zhang F, Tong Y, Su N, Li Y, Tang L, Huang L, et al. Weight loss effect of glucagon-like peptide-1 mimetics on obese/overweight adults without diabetes: a systematic review and meta-analysis of randomized controlled trials. J diabetes (2015) 7(3):329-39. doi:10.1111/1753-0407. 12198

214. FDA, USA. FDA Approves Weight-Management Drug Saxenda [Press release]. (2014). Retrieved from: http://www.fda.gov/NewsEvents/Newsroom/ PressAnnouncements/ucm427913.htm

215. EMU, EU. Saxenda Recommended for Approval in Weight Management in Adults [Press release]. (2015). Retrieved from: http://www.ema. europa.eu/ema/index.jsp?curl=pages/news_and_events/news/2015/01/ news_detail_002255.jsp\&mid=WC0b01ac058004d5c1

216. Sadry SA, Drucker DJ. Emerging combinatorial hormone therapies for the treatment of obesity and T2DM. Nat Rev Endocrinol (2013) 9(7):425-33. doi:10.1038/nrendo.2013.47

Conflict of Interest Statement: The authors declare that the research was conducted in the absence of any commercial or financial relationships that could be construed as a potential conflict of interest.

Copyright (C) 2017 Sekar, Wang and Chow. This is an open-access article distributed under the terms of the Creative Commons Attribution License (CC BY). The use, distribution or reproduction in other forums is permitted, provided the original author(s) or licensor are credited and that the original publication in this journal is cited, in accordance with accepted academic practice. No use, distribution or reproduction is permitted which does not comply with these terms. 